\title{
Nerabeen gaitasun sozial eta emozionalak garatzeko programak: berrikusketa
}

\author{
Ainize Sarrionandia Peña \\ Maite Garaigordobil Landazabal \\ Nortasuna, Balioespena eta Psikologia Tratamendu Saila \\ Psikologia Fakultatea \\ Euskal Herriko Unibertsitatea UPV/EHU
}

DOI: $10.1387 / \operatorname{tantak.17483}$

GAKO-HITZAK: adimen emozionala; programak; nerabezaroa; berrikusketa.

\section{SARRERA}

Adimen emozionala (AE) kontzeptuaren historia laburra bada ere, duela mende asko hasi ziren erabiltzen haren aurrekariak. Azken hogeita bost urteetan, AE kontzeptuak interes handia piztu du, eta ikertzaile askok aztertu dute gai hori. Gaur egun hainbat eredu daude AEren inguruan; Haietatik ezagunenak Saloveyen eta Mayeren gaitasun eredua eta Petridesen eta Furnhamen ezaugarri eredua izan arren, eredu misto batzuk ere badaude, adibidez, Bar-Onena eta Golemanena. Gaitasun gisa ulertuta, AE emozioekin erlazionaturiko gaitasun kognitibo gisa definitu izan da, zeinak emozioak hauteman, erabili, ulertu eta kudeatzeko gaitasuna inplikatzen baitu (Mayer, Salovey eta Caruso, 2004). Ezaugarri gisa ulertuta, AE nortasunaren oinarrian kokatzen den konstruktua izango litzateke; hau da, nortasunaren hierarkian azpiko mailetan kokatzen diren hautemate emozionalen multzoa (Petrides eta Furnham, 2001). Azkenik, izaera mistodun aldagaitzat hartuta, AE nortasun ezaugarrien eta gaitasun emozionalen arteko batura izango litzateke. Hala, Golemanek (1995) AE definitzen du norbere eta besteen sentimenduak ezagutzeko, motibatzeko eta harremanak (besteekin eta norberarekin) kudeatzeko gaitasun gisa.

AE kontzeptuak «adimen» eta «emozio» kontzeptuak hartzen ditu bere baitan. Adimen edo inteligentzia hitza latineko intelligentĭa hitzetik dator, eta adierazten du irtenbide baten bilaketan aukera onenak bilatzeko gaitasuna. Adimena da informazioa pentsatu, ulertu, barneratu eta lantzeko 
gaitasuna, betiere informazio hori modu egokian erabilita. Harluxet Hiztegi Entziklopedikoak honela definitzen du adimena: «Ulertzeko ahalmena, pentsamendu bidez nor bere buruaz eta inguruaz jabetzeko ahalmena» edo «Egoera bati aurre egiteko, arazo bati irtenbidea emateko, zirkunstantzien arabera aukera egiteko ahalmena». Emozio hitzaren sustrai etimologikoa latineko movere (mugitu) hitzetik dator, eta «e» aurrizkiak «-rantz» esan nahi du. Emozioek, beraz, mugimendurako edo ekintzarako joera inplikatzen dute. Harluxet Hiztegi Entziklopedikoaren arabera, emozioa da «Une batez eta bat-batean, gizabanakoaren egitura psikofisikoaren oreka aldatzen duen egoera afektiboa». Bi ideia horiek lotuz gero, AE izango da emozioak ulertu eta egoera emozionalei aurre egin edo irtenbidea emateko ahalmena.

Ikerketek erakutsi dute AE bizitzako aldagai garrantzitsuenekin lotuta dagoela, hala nola zoriontasunarekin (Ruiz-Aranda, Extremera, eta Pineda-Galán, 2014), ongizate psikologikoarekin (Mikolajczak, Roy, Luminet, Fillée, eta de Timary, 2007), lan errendimenduarekin (O'Boyle, Humphrey, Pollack, Hawver, eta Story, 2011), harreman sozial eta ezkontzakoekin (Kotsou, Grégoire, Nelis, eta Mikolajczak, 2011) eta osasunarekin (Mikolajczak et al., 2015). Beraz, gaitasun sozialak eta konpetentzia emozionalak hobetzeak lagundu dezake egun gure gizartean ohikoak diren arazoak (bullyinga, arrazakeria, sexismoa, estresa, depresioa...) saihestu eta konpontzen. Hori kontuan harturik, azken hamarkadetan AE hobetzeko hainbat programa diseinatu eta ebaluatu dira.

Programa horien helburua da gaitasun sozial eta emozionalak, jarrerak, jokaerak eta alderdi akademikoa hobetzea, eta haien baliotasuna eta eraginkortasuna frogatu dira (Durlak, Weissberg, Dymnicki, Taylor eta Schellinger, 2011). Euskal Herrian ere egin dira esku-hartze batzuk gaitasun sozial eta emozionalak hobetzeko. Salazarrek (2012), adibidez, 1012 urte bitarteko haurren gaitasun emozionalak eta eskola elkarbizitza positiboa bultzatzeko esku-hartze bat diseinatu eta ebaluatu zuen. Emaitzek erakutsi zutenez, programak gatazken maiztasuna gutxiagotu zuen, eta ikasleek gatazkak modu baketsuan erregulatzen ikasi zuten. Bestalde, ikasleriaren autoezagutza areagotu zen, eta kontzientzia emozionalaren garapenean aurreratu. Eskolako indarkeria fisikoa eta ikasle batzuen bazterketa gutxitu egin ziren, baina hitzezko indarkeria mantendu egin zen. Azkenik, ikasle-ikasleen zein irakasle-ikasleen arteko harremanak hobetu egin ziren. Beraz, esku-hartze horri esker elkarbizitza nabarmenki hobetu zen (Salazar, 2012).

Gaur egun ohikoak dira bullyinga, arrazakeria, sexismoa, bakardadea, depresioa, oldarkortasuna eta beste hainbat arazo, eta horren adierazle da Osasunaren Mundu Erakundeak (OME, 2014) eman zuen datu bat, hots: suizidioa da 15-29 urte bitarteko populazioaren bigarren heriotza arrazoia mundu mailan, eta kanpo heriotzaren lehenengo arrazoia Espainian. Berrogei segundoan behien pertsona batek bere buruaz beste egiten du munduan, eta, hala, urtean 800.000 pertsonak hiltzen du bere burua. Bestalde, 
indarkeriari loturiko arazoak gehituz doaz. Euskal Herrian egindako ikerketa batek jaso zuen nerabeen (12-18 urte) \% 83,7 bullying egoera batean (biktima, erasotzaile edo behatzaile gisa) inplikatua izan zela, eta, $\%$ 69,8, cyberbullyingean (Garaigordobil, 2013). Azkenik, Nazio Batuen txosten batean jaso denez, kutsagarriak ez diren gaixotasunen eta gaixotasun mentalen ondoriozko gastua 46,7 trilioi dolarrekoa izango da datozen 20 urteetan (Bloom, 2011). Arazo horiek guztiek faktore komun bat dute: AEarekiko erlazioa. Izan ere, arazo horiek nabarmenki hobetuko lirateke autoestimua hobetuz, enpatia garatuz, emozioak eta bulkadak kudeatzen ikasiz, gaitasun sozialak landuz, emozioen adierazpena hobetuz edo norbere burua hobeto ezagutuz. Beraz, gaitasun sozioemozionalak garatzeko programa psikoedukatiboak onuragarriak dira, bai aurrez aipatutako arazoak saihesteko, bai eta arazo horiek agertu direnean esku-hartzeko ere.

Hori guztia kontuan hartuta, lan honen helburua izan da nerabezaroan $\mathrm{AE}$ eta gaitasun sozioemozionalak hobetzeko programa psikoedukatiboei buruzko literatura zientifikoa berrikustea. Hau da, lan honen asmoa egun arte zientifikoki ebaluatuak izan diren esku-hartze programak bilatzea izan da gaitasun sozioemozionalak hobetzeko programen emaitzak aztertzea helburu izanik.

\section{METODOLOGIA}

Helburu hori lortzeko, eta AE hobetzeko esku-hartze programen ikuspegi holistiko bat eskaintzeko asmoz, bibliografia bilaketa sakon eta sistematikoak egin dira liburuetan (ISBN) eta hainbat datu basetan; besteak beste, PsycINFO, ERIC, Scopus eta Google Akademikoa datu baseetan. Bilaketa horiek 2015. urtera arte argitaratutako materialean zentratu dira, eta bilaketetan termino hauek erabili dira: adimen emozionala, gaitasun sozialak/emozionalak, programa eta nerabezaroa (bai ingelesez bai gaztelaniaz). Termino hauek erabiliz bilaketak egin eta aurkitutako artikuluak irakurri dira. Aurkitutako artikulu guztiak kodifikatzeko asmoz hainbat hautespen irizpide erabili dira. Zehazki, berrikusketa hau nerabezaroan oinarritzen da, lagin osasuntsuetan eta talde naturaletan. Horrela bada, irizpide hauek betetzen ez dituzten eta esku-hartze programei erreferentzia egiten ez dien artikuluak baztertu ziren eta geratzen ziren programak taula batean bildu dira oinarrizko informazioa erakusten. Kontuan hartu den beste irizpide bat ebaluazioarena izan da; izan ere, berrikusketa honetan ebaluatutako programak besterik ez ditugu jaso.

Artikulu honen garapenerako erabilitako metodologiak erantzun nahi die ondorengo galderei: ze helburu dituzte AE programek? Ze adin tartetan erabiltzen dira? Ze motatako ebaluazio tresnak (eta zeintzuk konkretuki) erabiltzen dira programa horien eraginak neurtzeko? Ze programa dira eraginkorrenak? 


\section{EMAITZAK}

Bilaketa horietan, gaitasun sozialak eta emozionalak hobetzen dituzten 32 programa aurkitu dira; haietariko 6k AE hobetzea dute helburu, eta beste $26 \mathrm{k}$, aldiz, gaitasun sozialak eta emozionalak hobetzea. Jarraian, programa horiek aurkezten dira 2 taulatan. Taula horietan agertzen dira programaren izena eta autoreak, lagina, programaren helburuak, edukiak, ikerketa diseinua, erabilitako tresnak eta emaitzak. Lehenengo taulan, «adimen emozionala» kontzeptua erabiltzen duten programak aurkezten dira, eta bigarrenean, gaitasun sozioemozionalak lantzen dituztenak. 


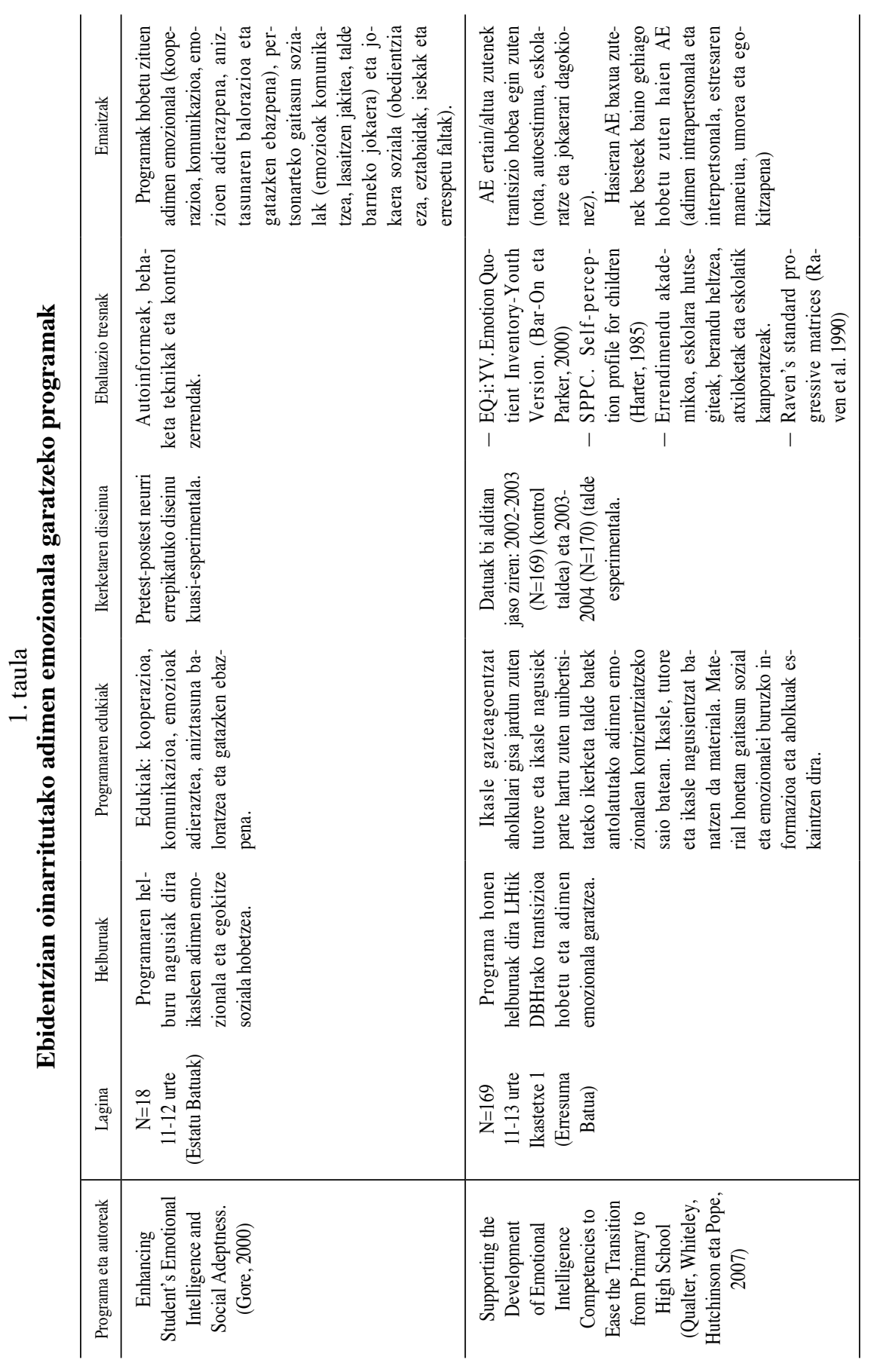

TANTAK, 28 (2), 2016, 111-148 orr. 


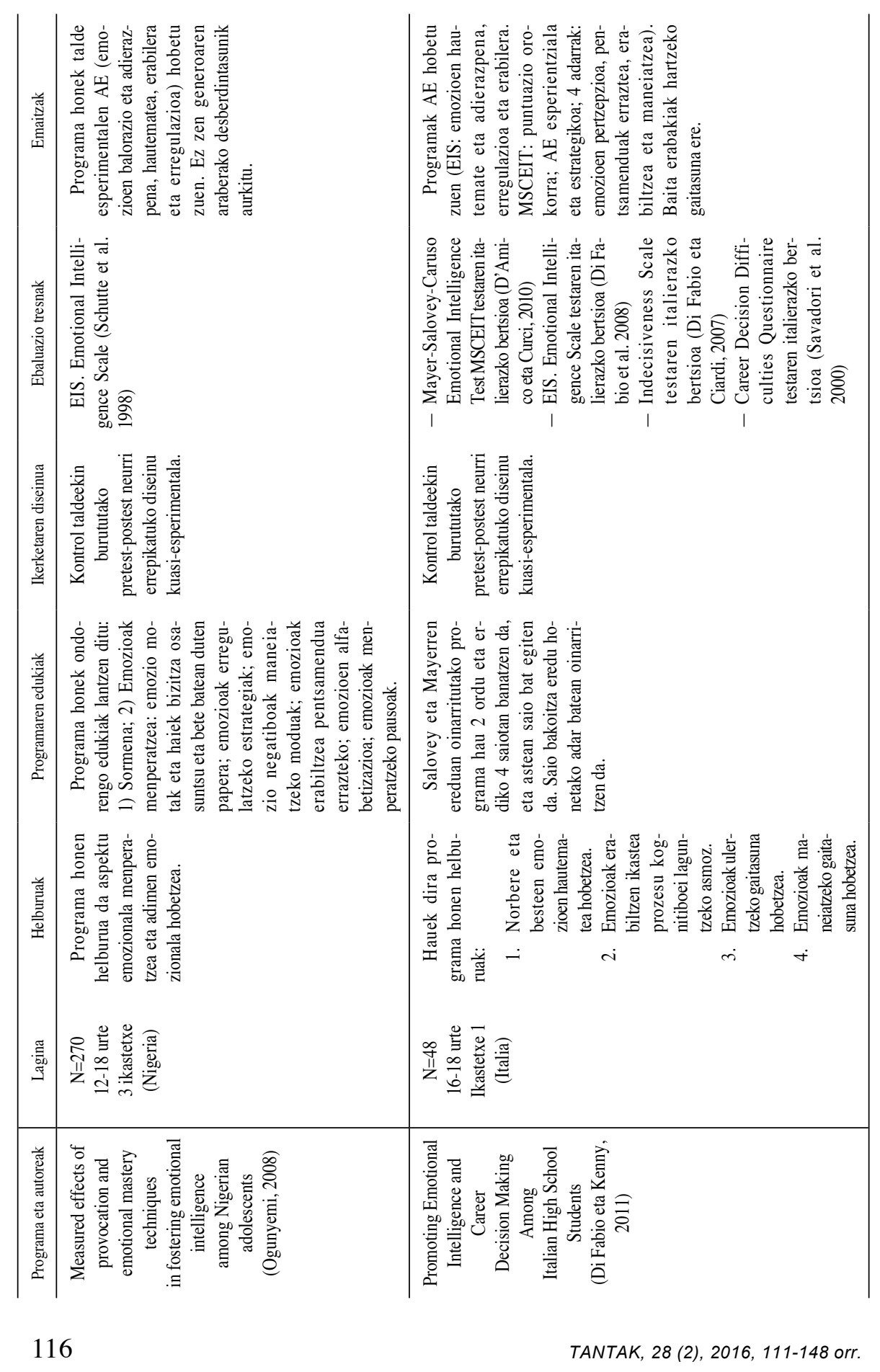




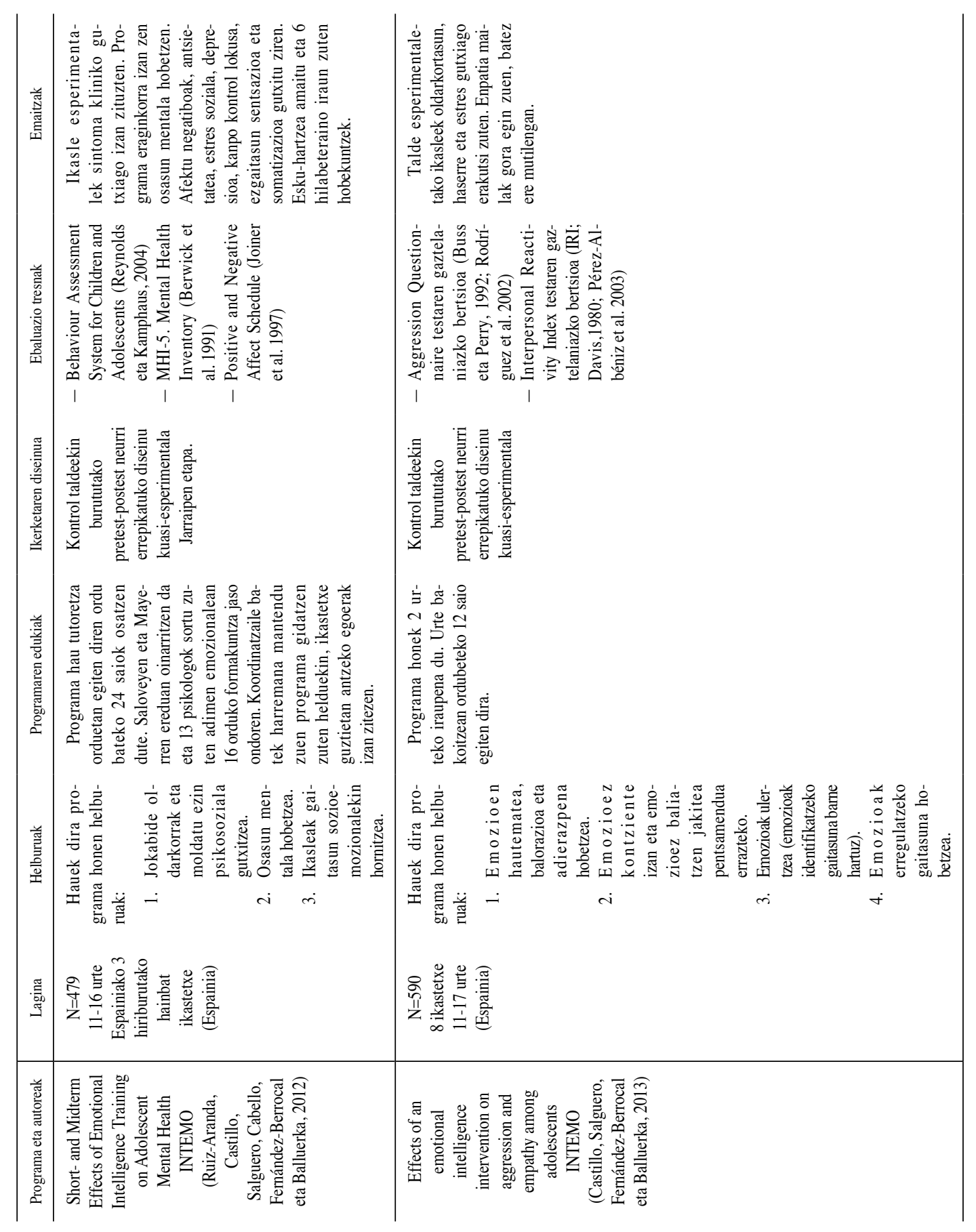




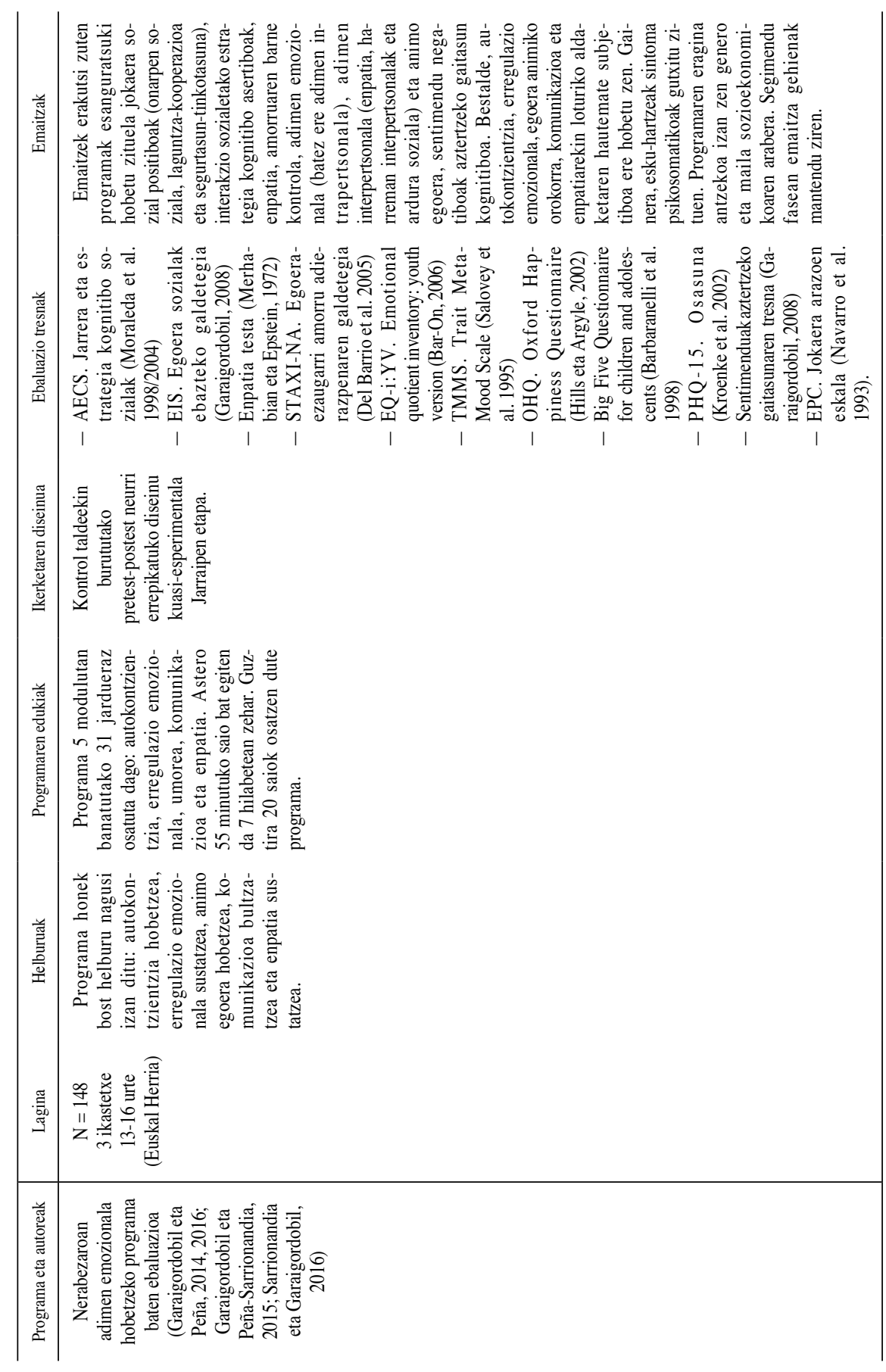




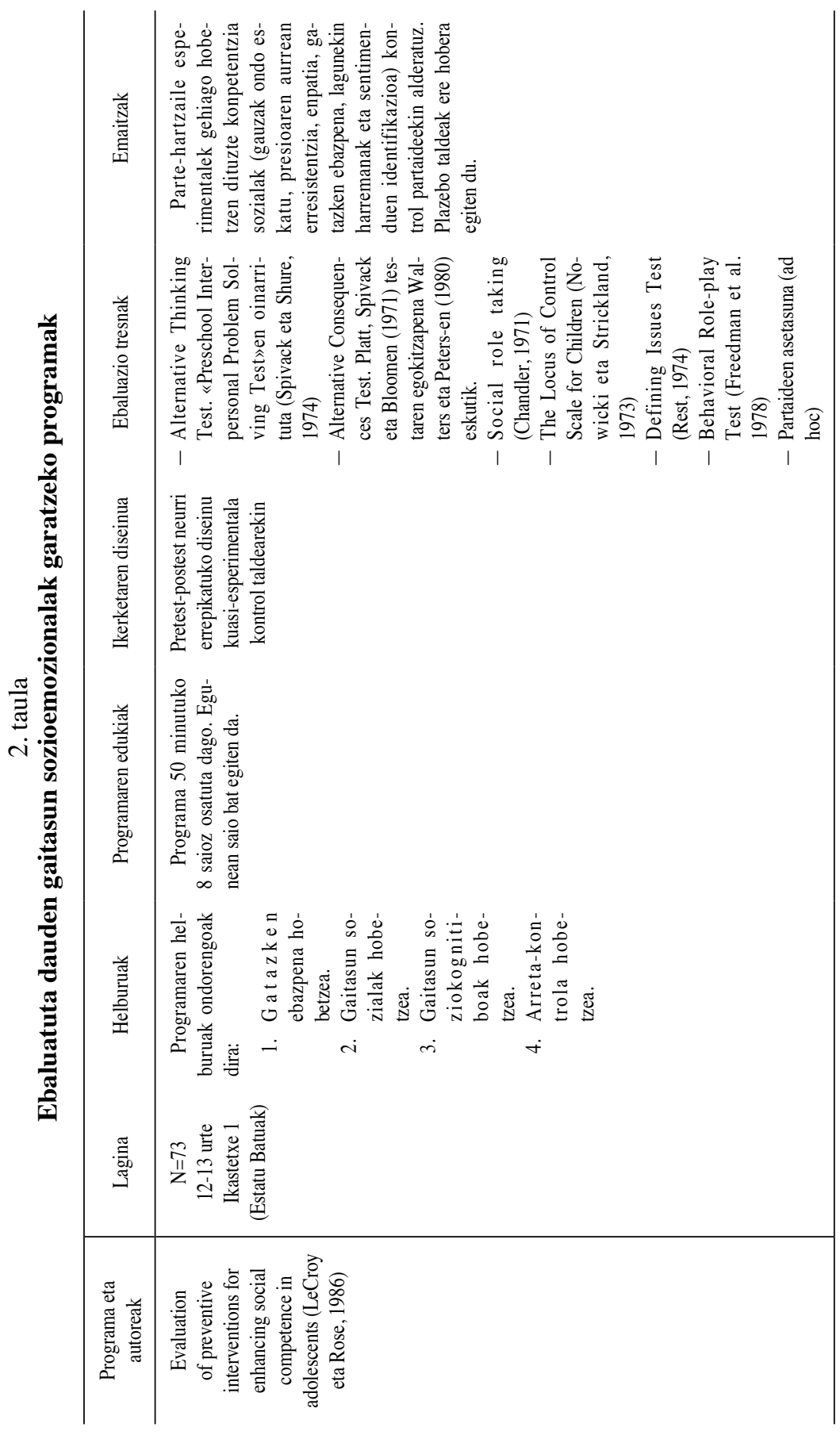

TANTAK, 28 (2), 2016, 111-148 orr. 


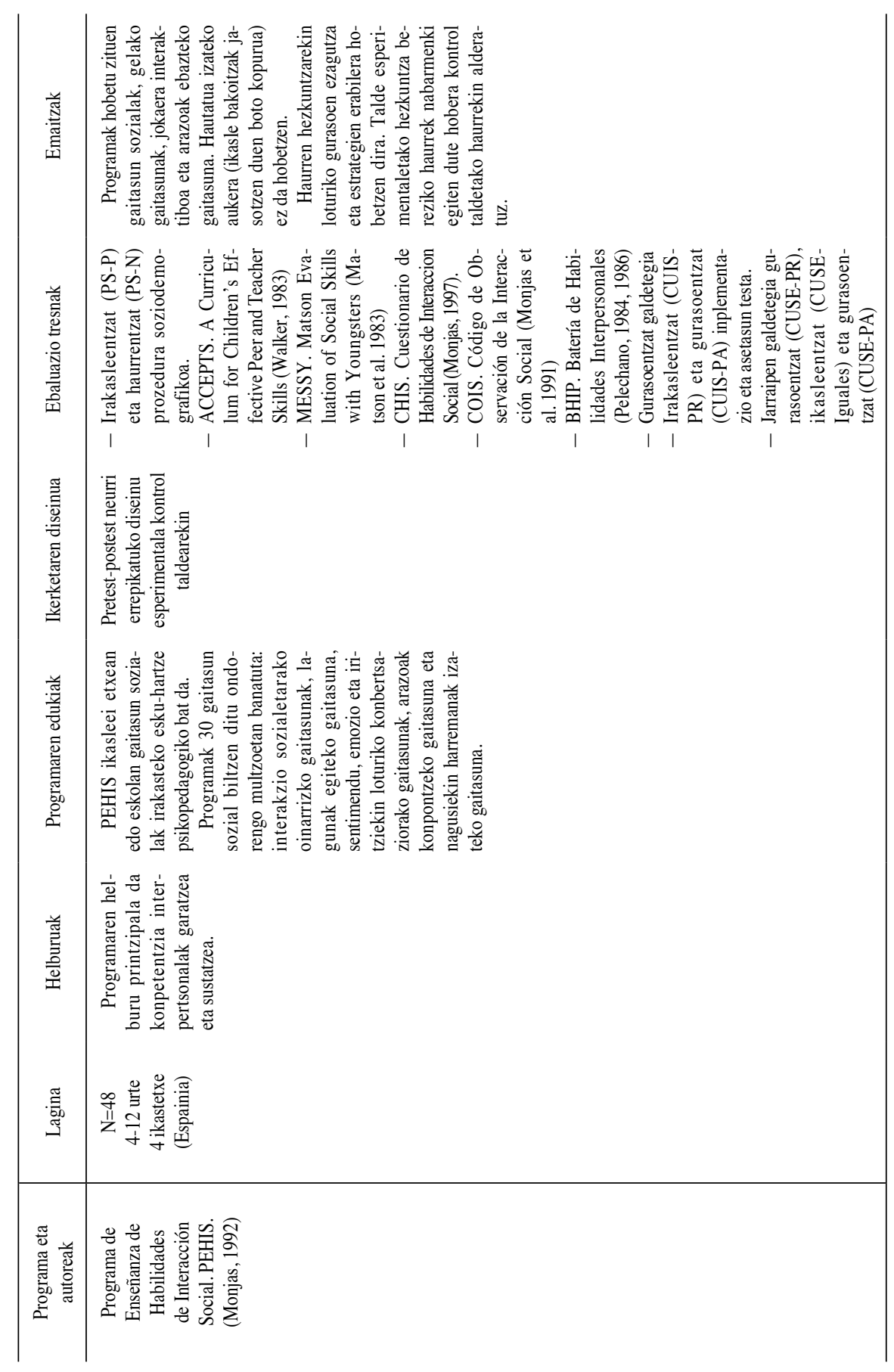




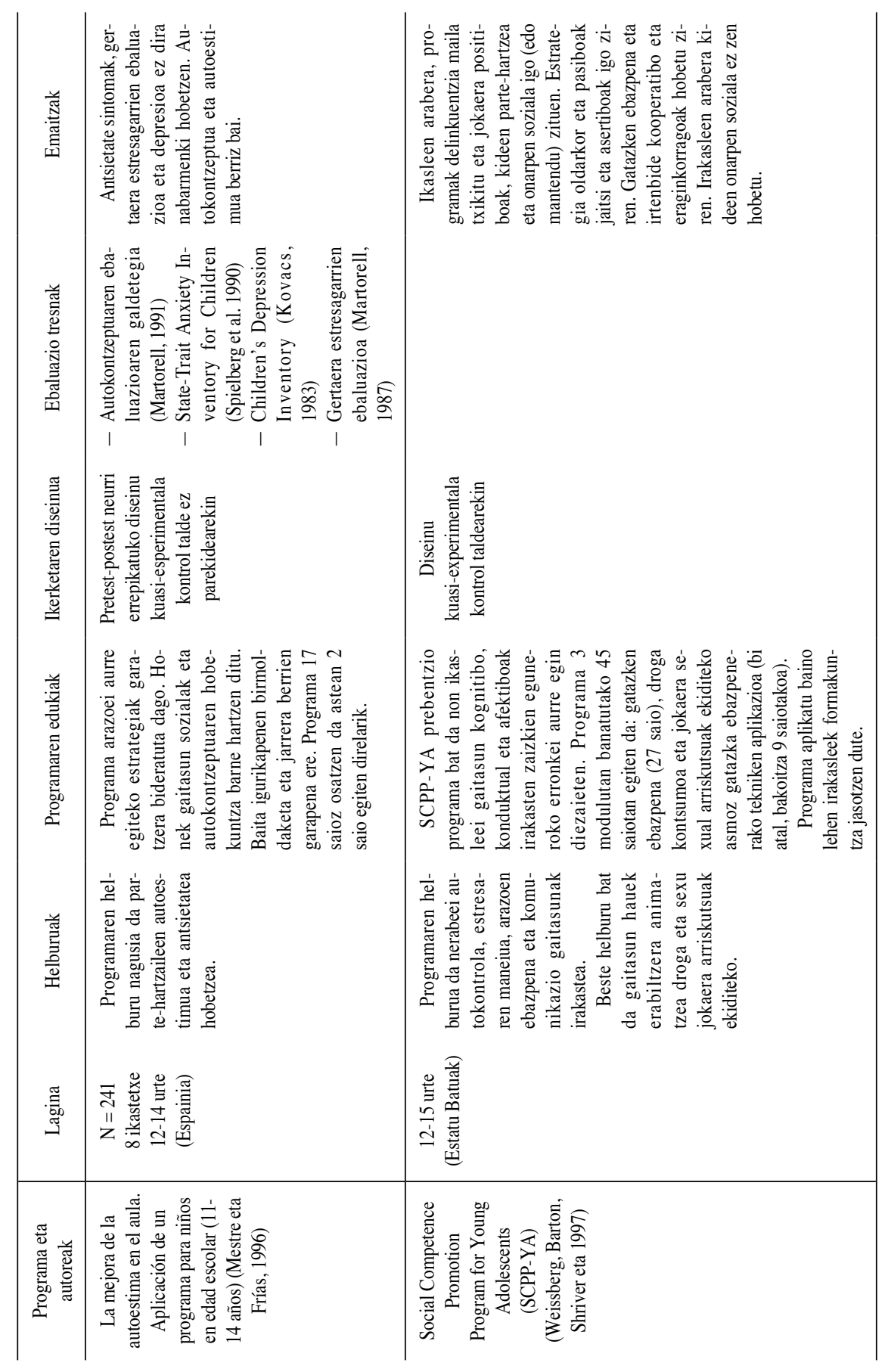

TANTAK, 28 (2), 2016, 111-148 orr. 


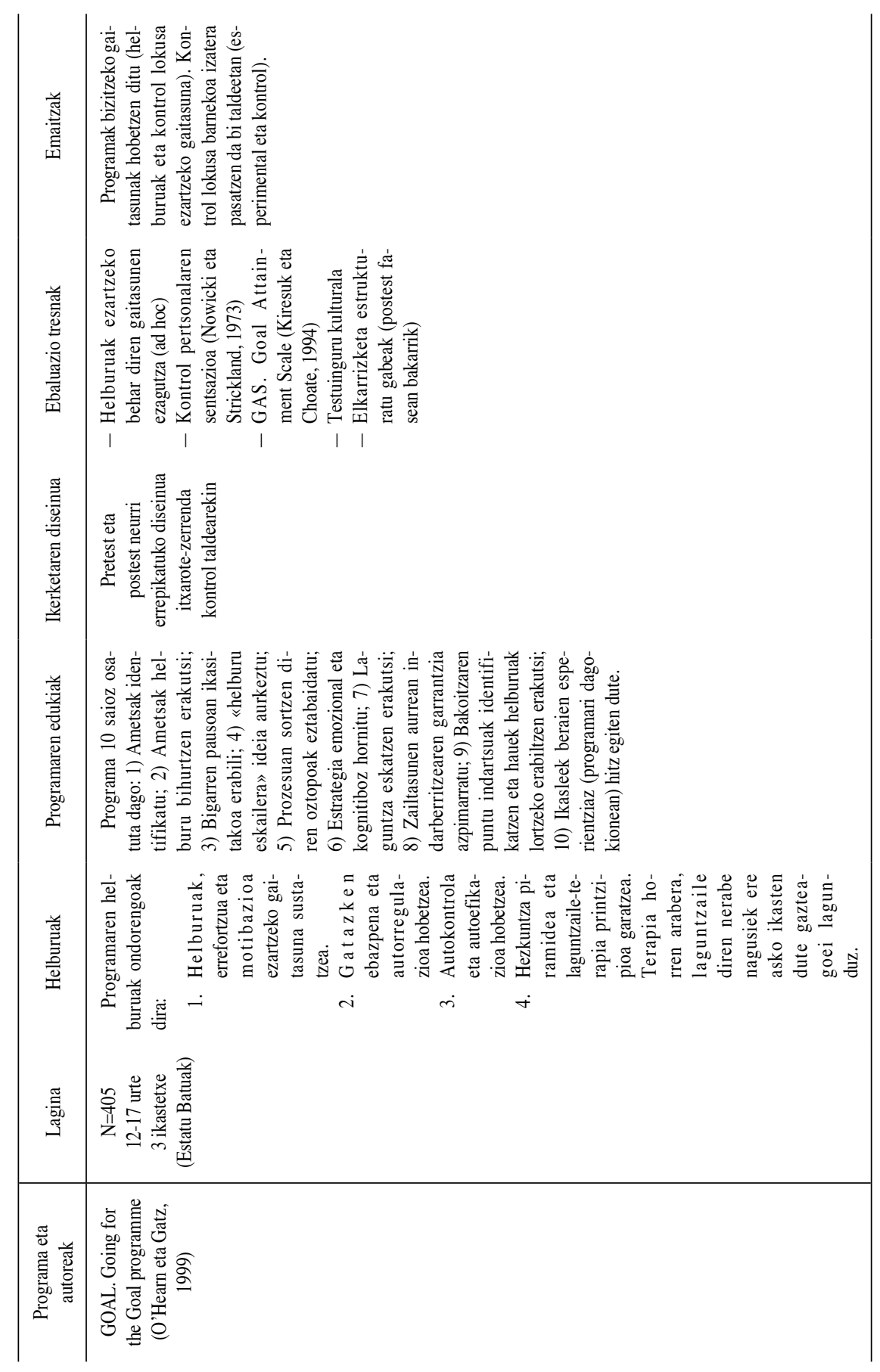




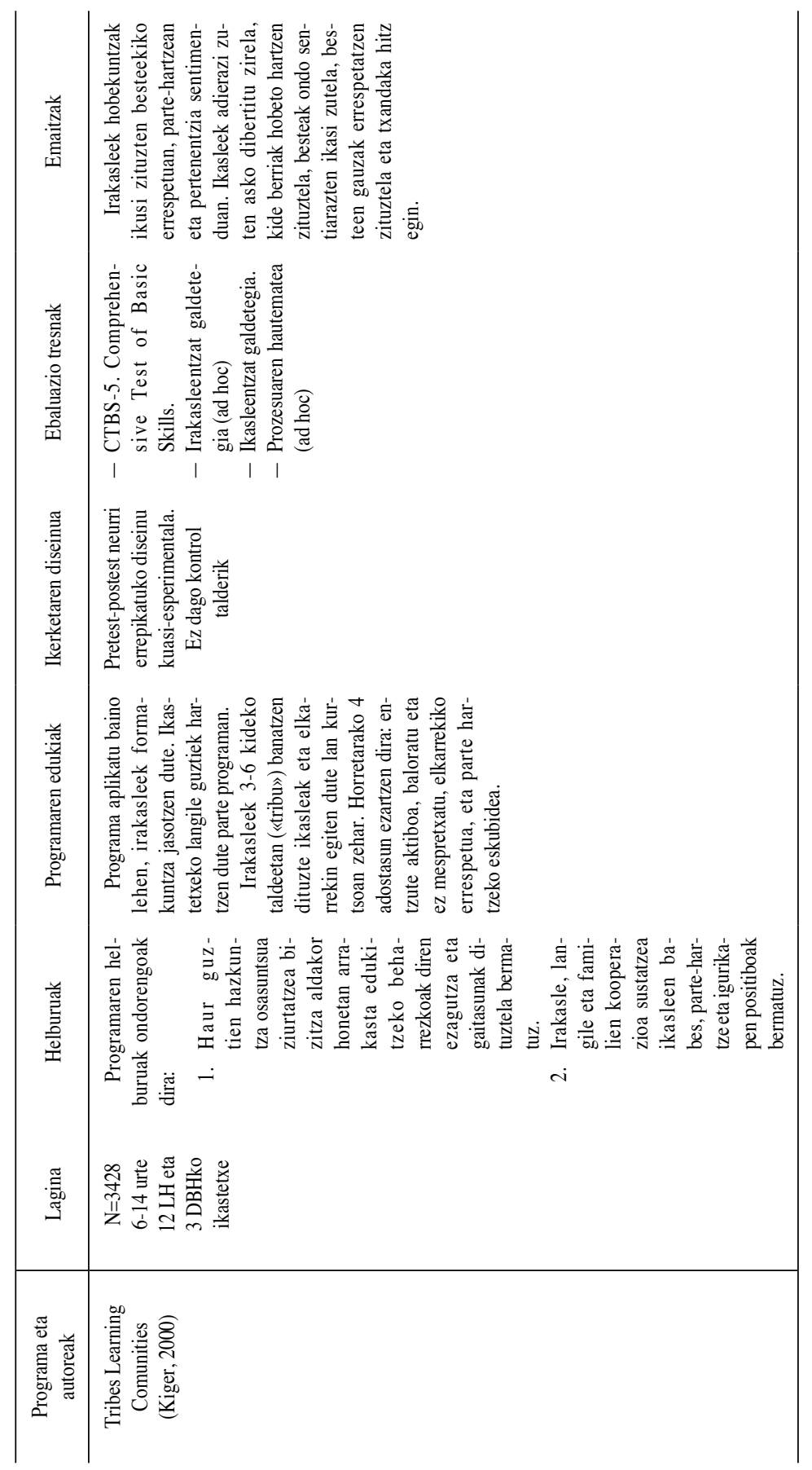

TANTAK, 28 (2), 2016, 111-148 orr. 


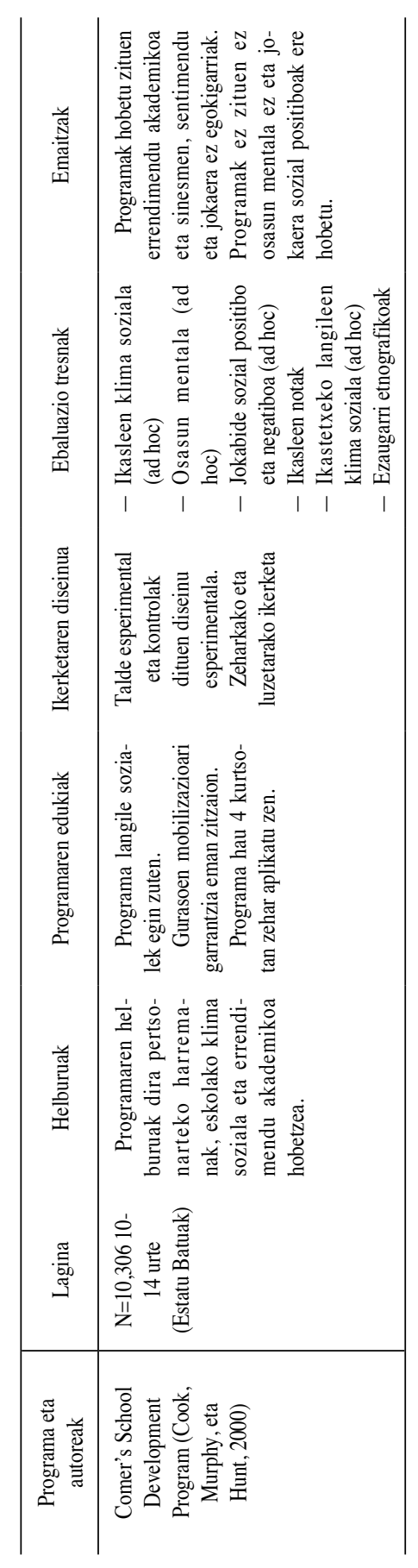




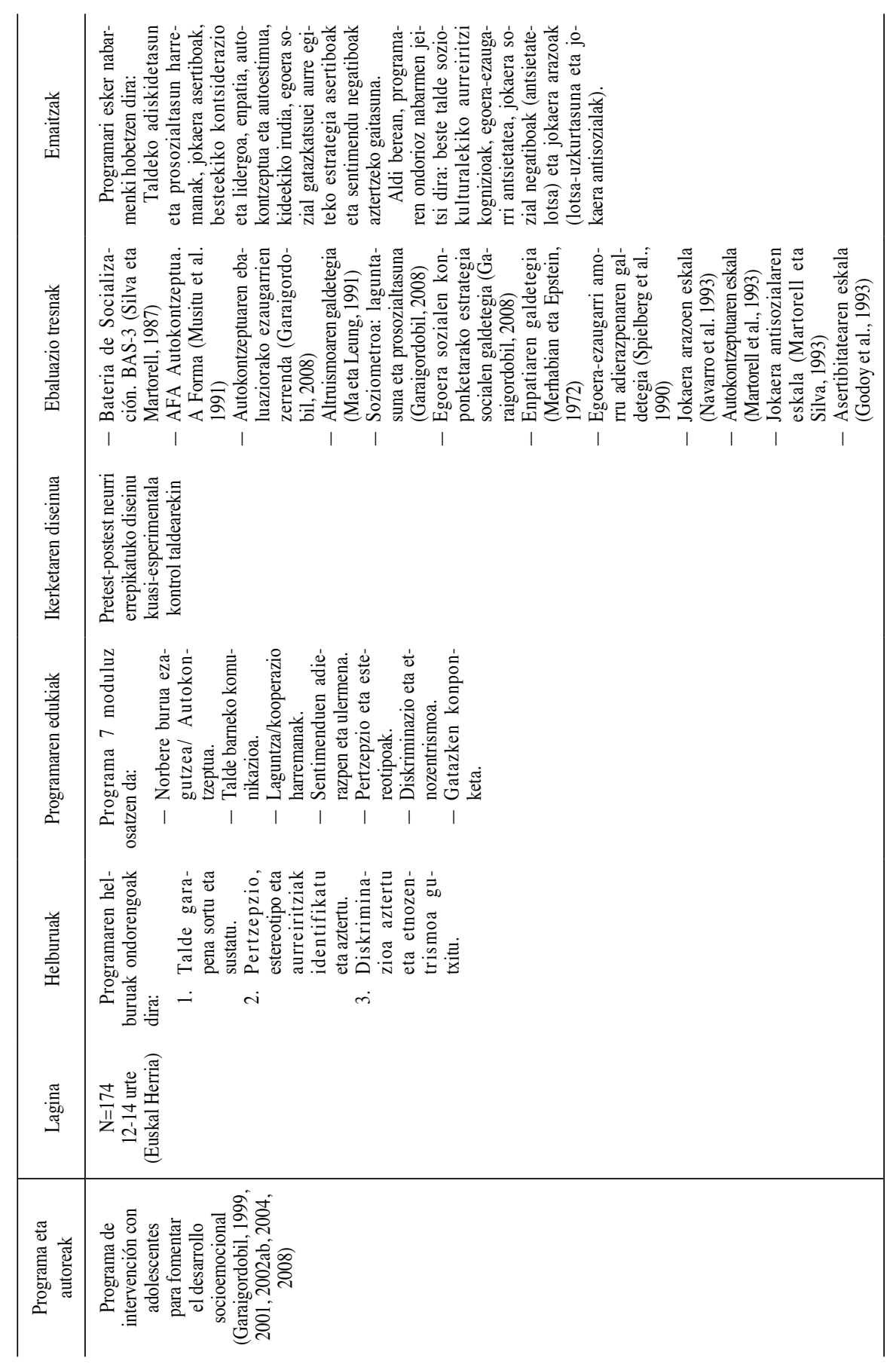




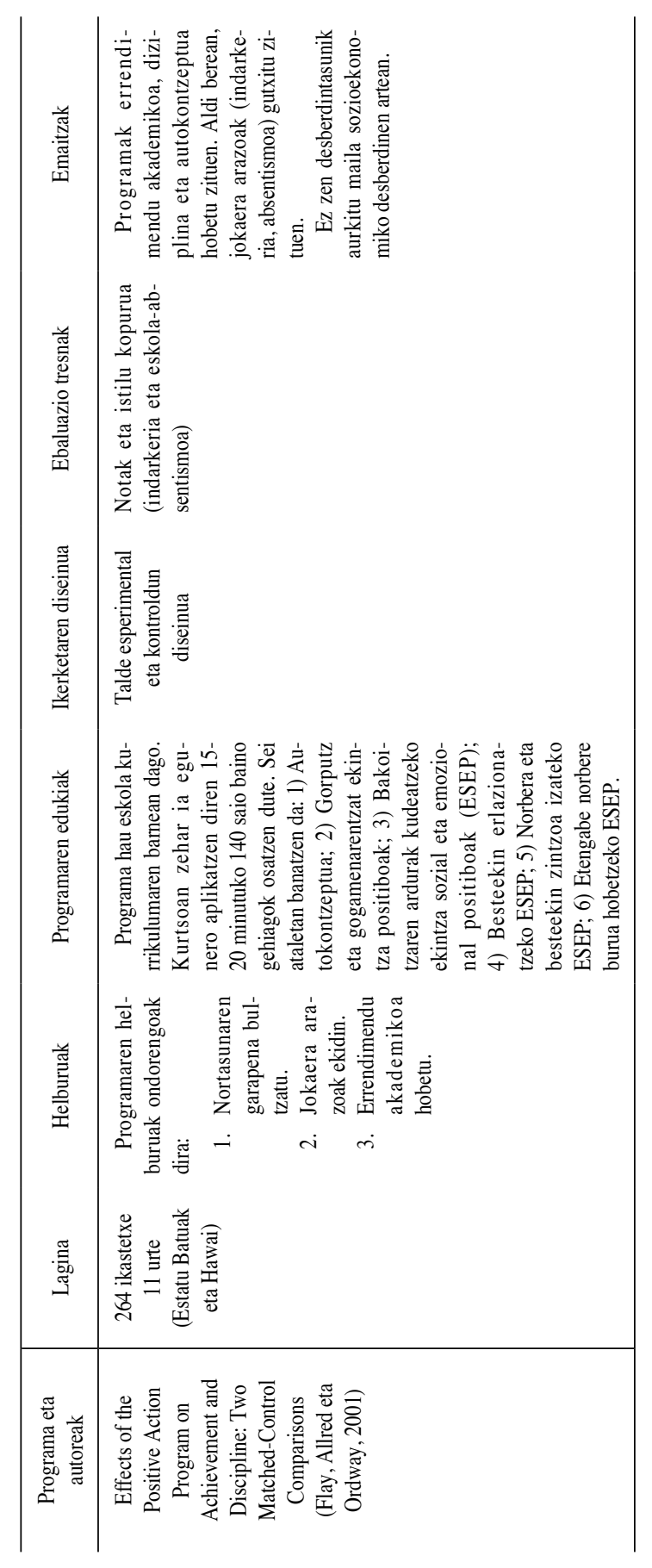




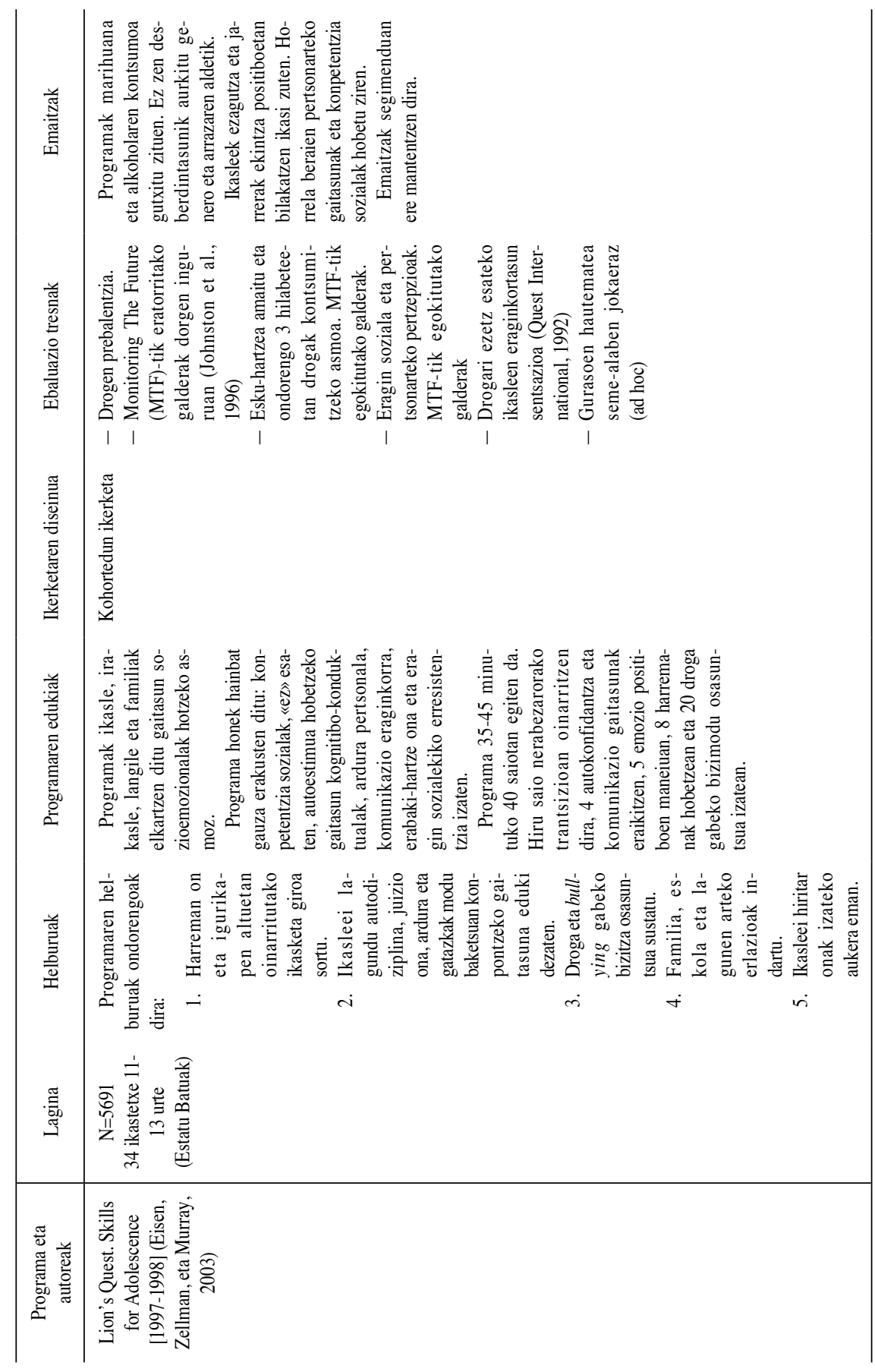

TANTAK, 28 (2), 2016, 111-148 orr. 


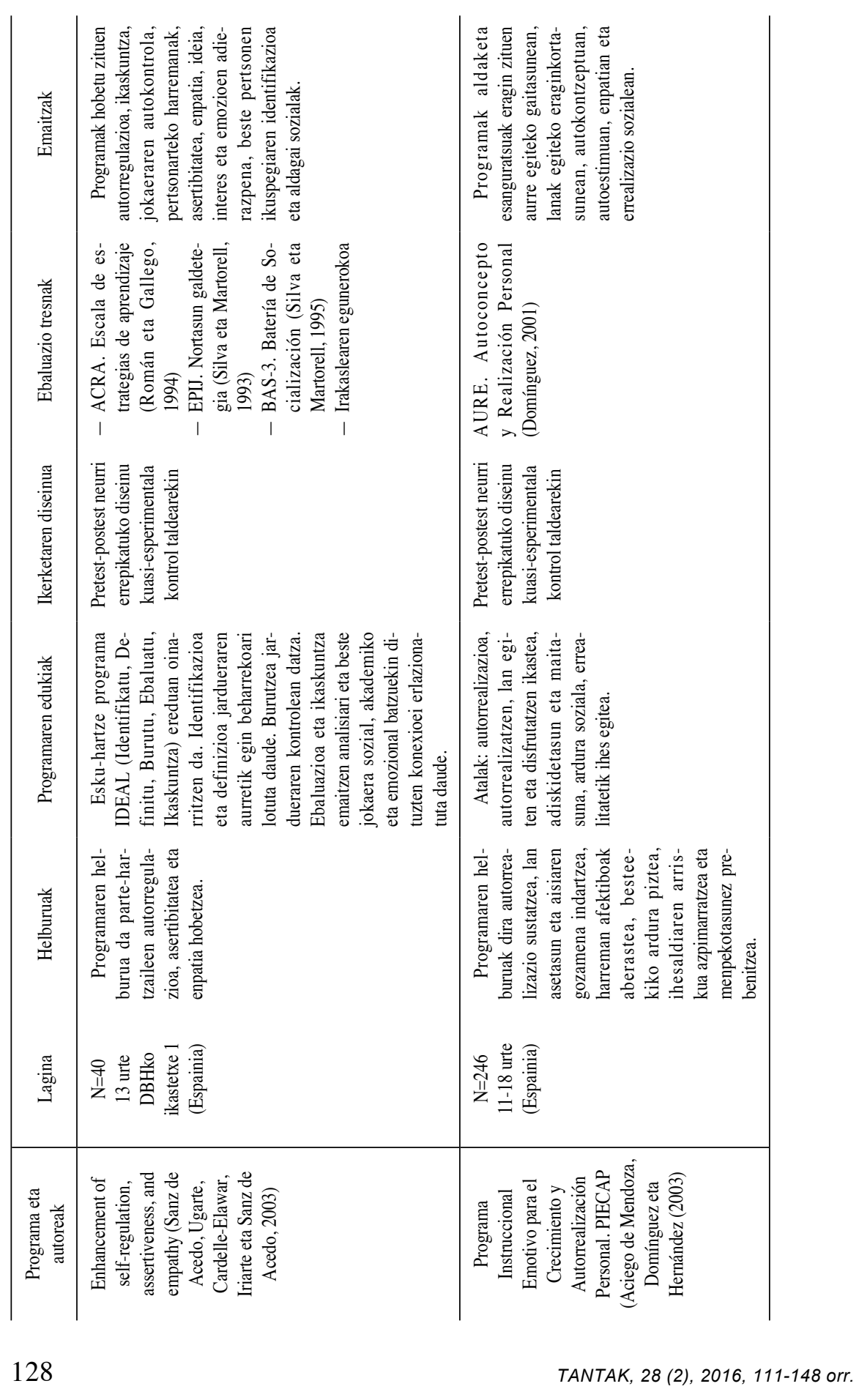




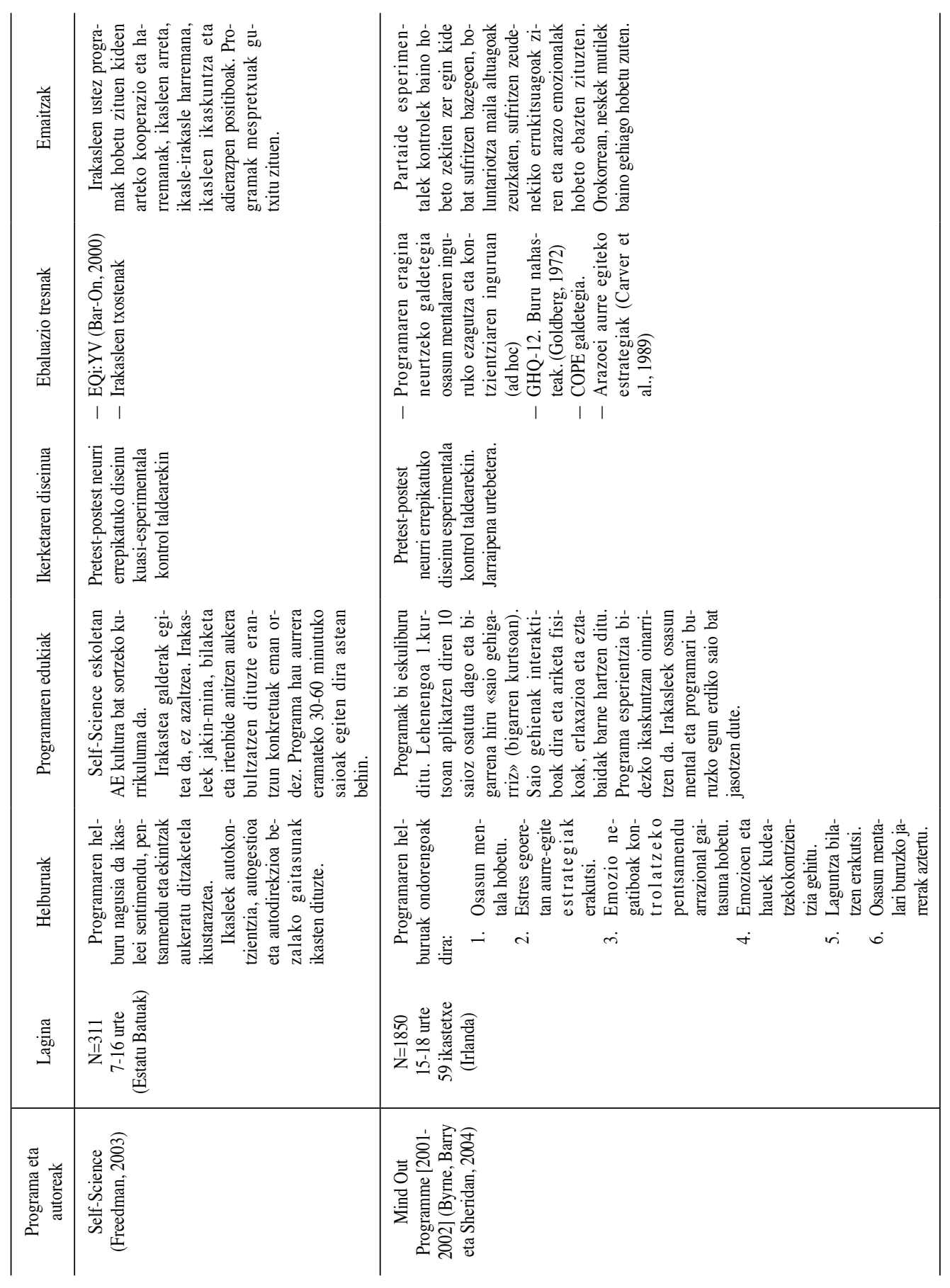

TANTAK, 28 (2), 2016, 111-148 orr. 


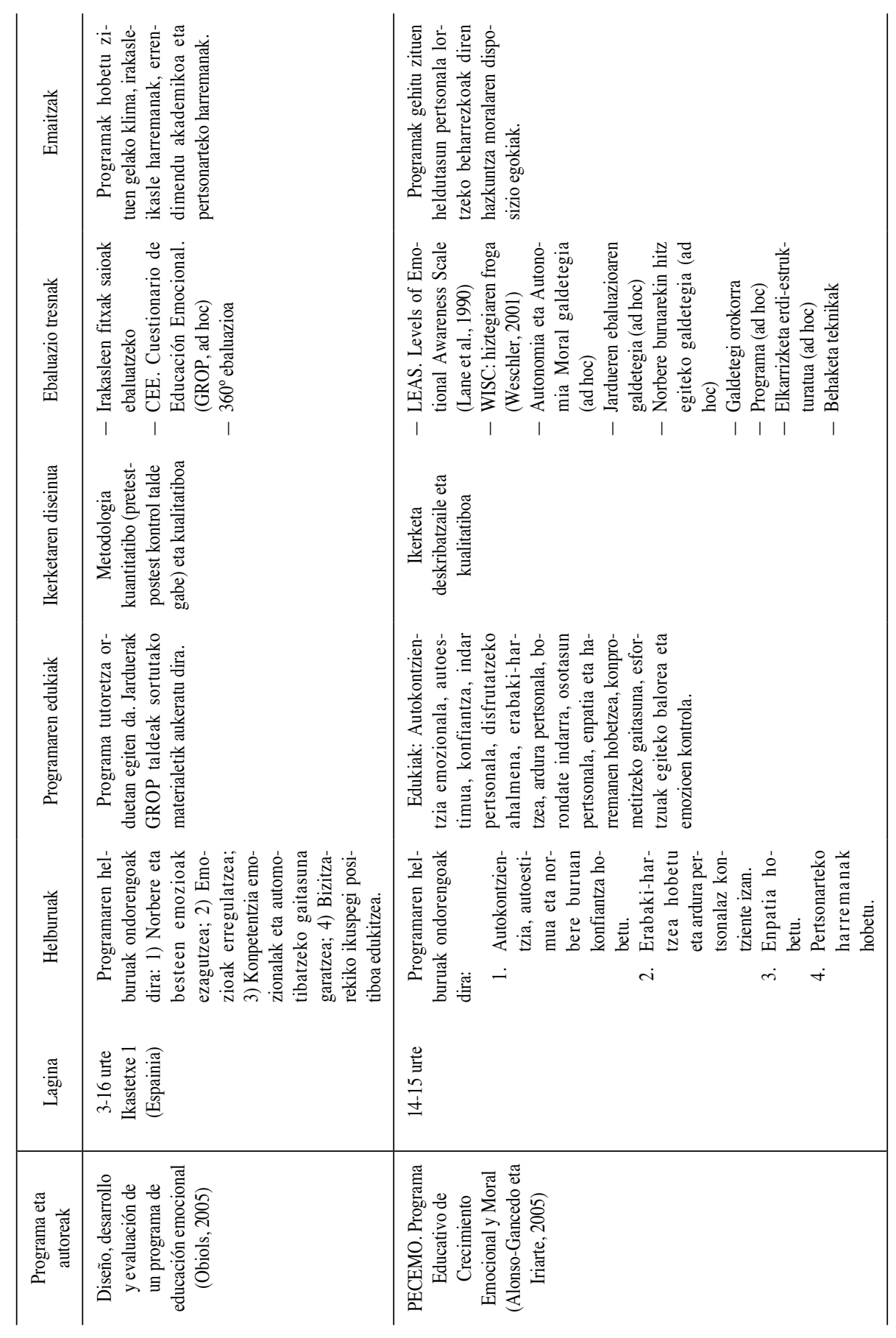




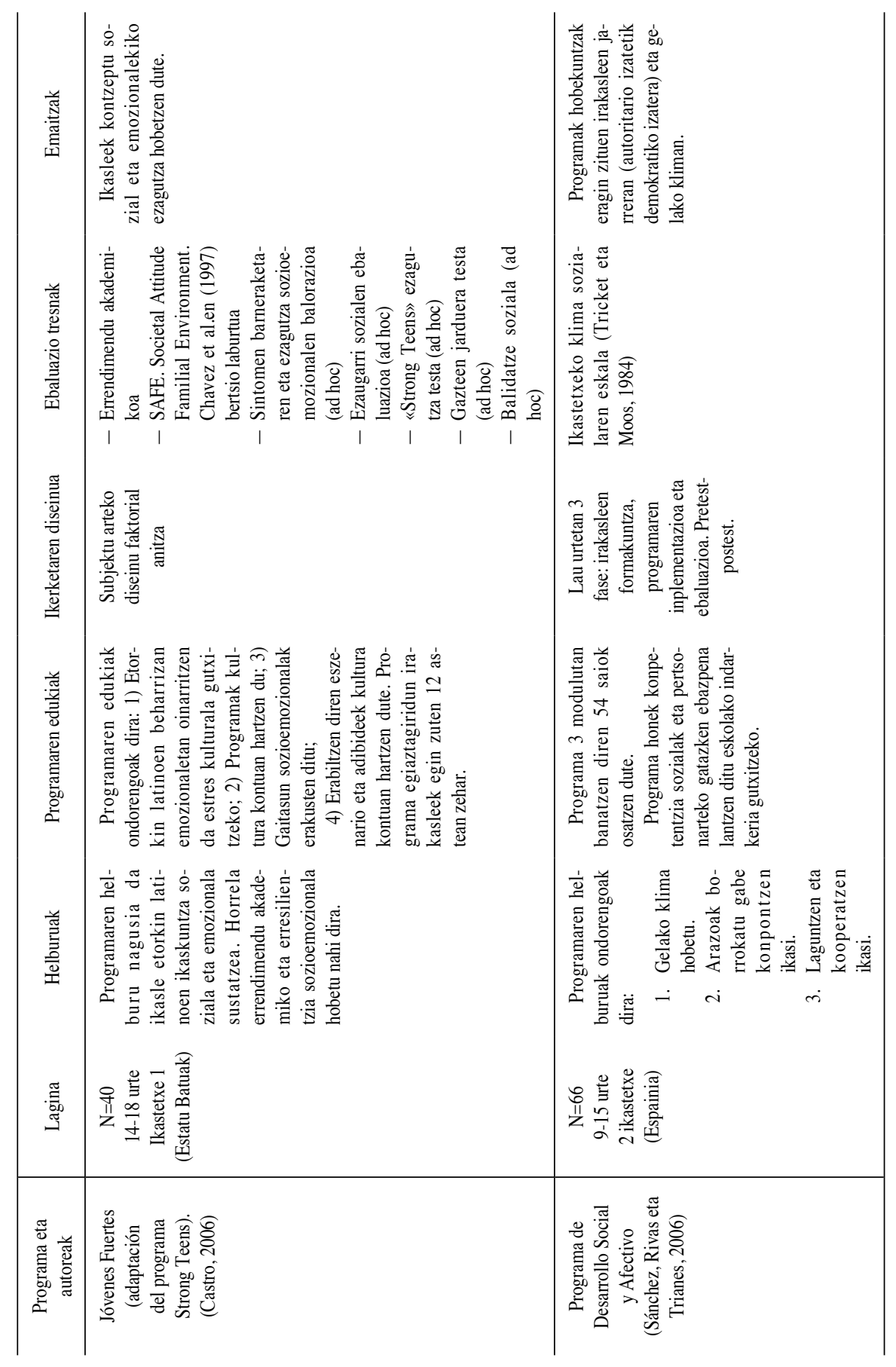

TANTAK, 28 (2), 2016, 111-148 orr. 


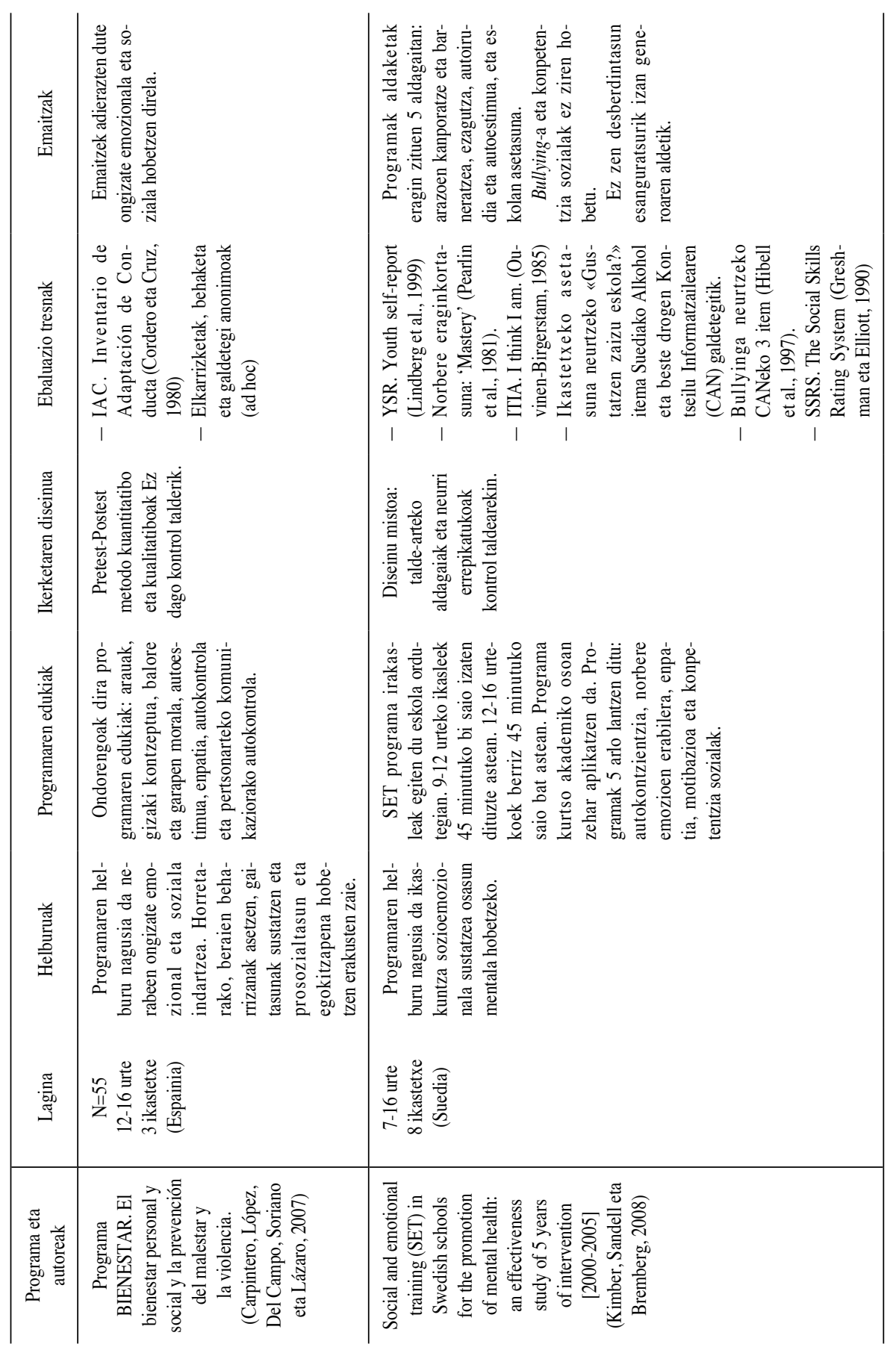




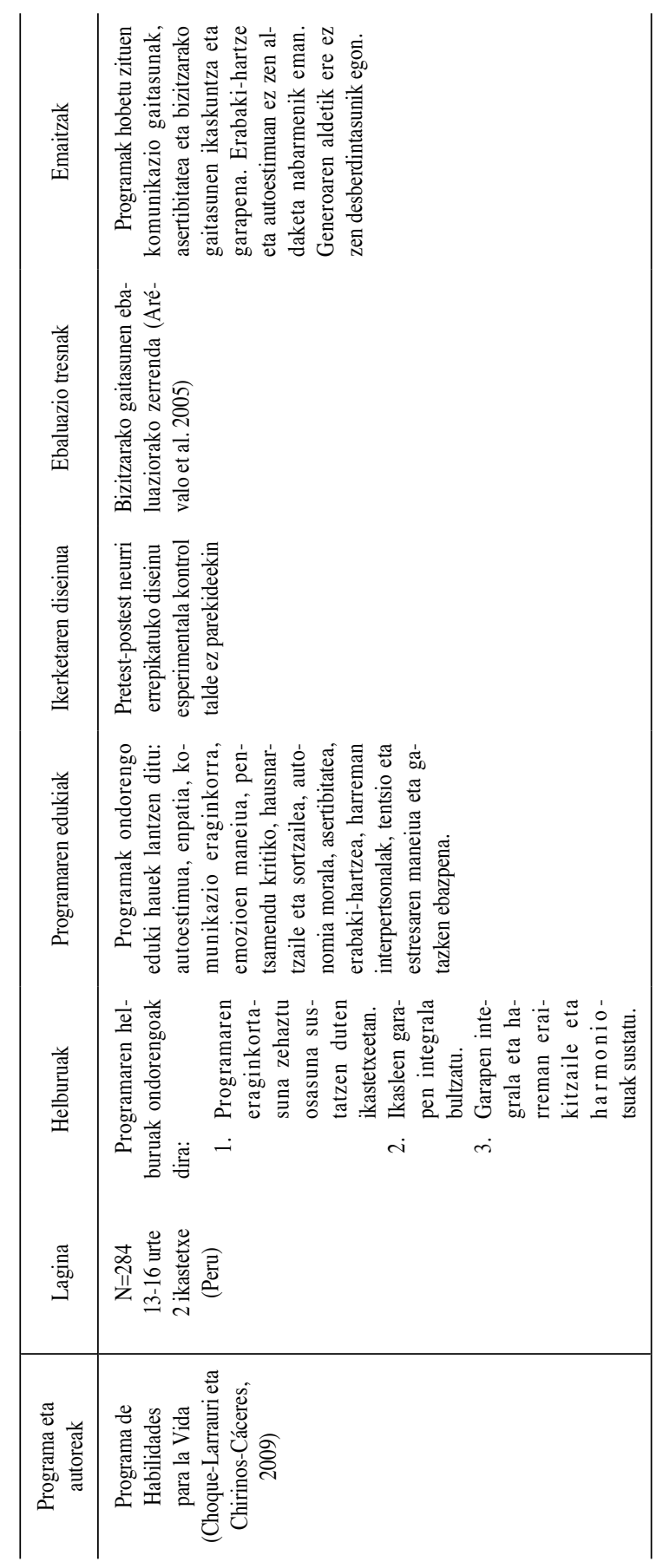

TANTAK, 28 (2), 2016, 111-148 orr. 


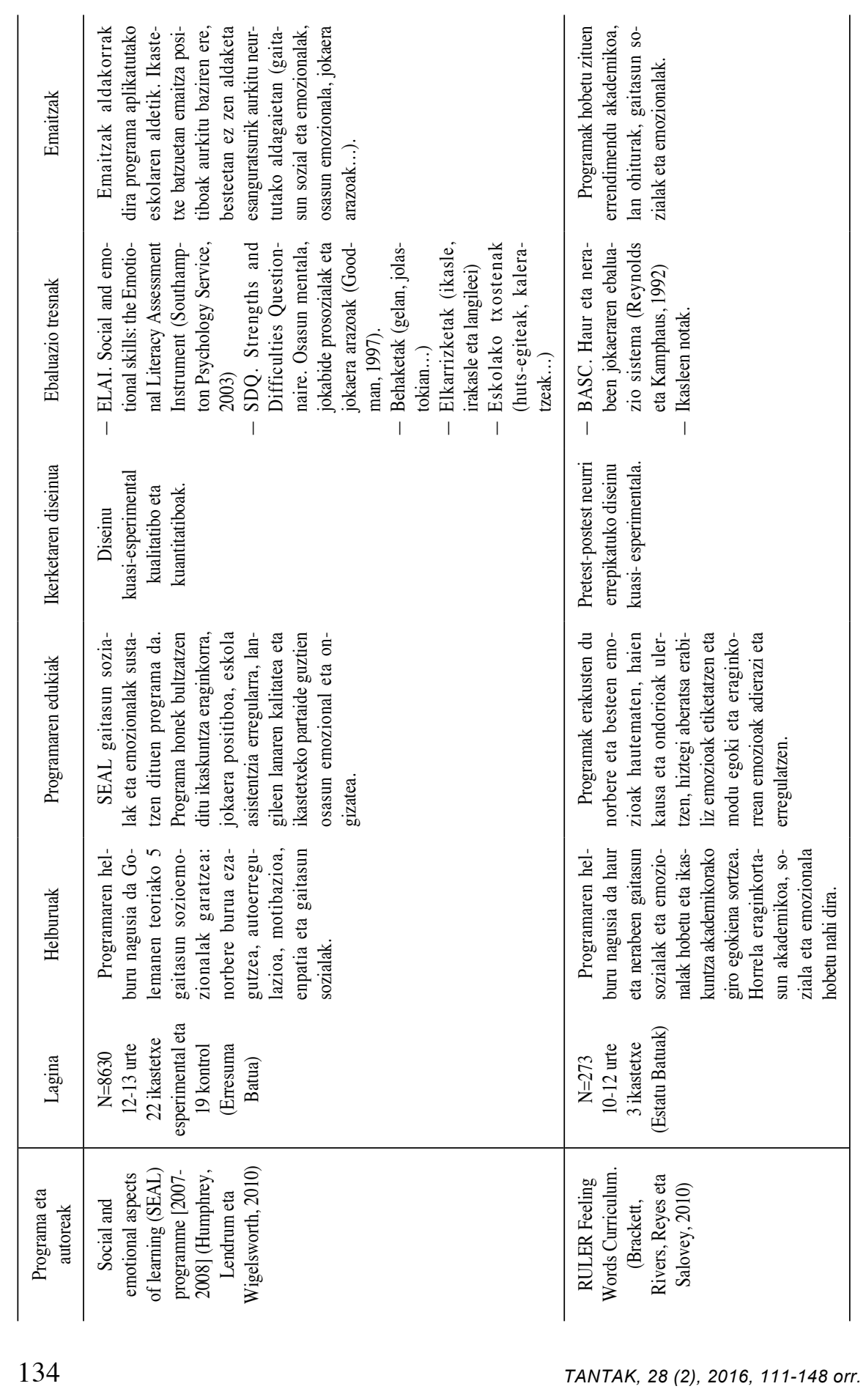




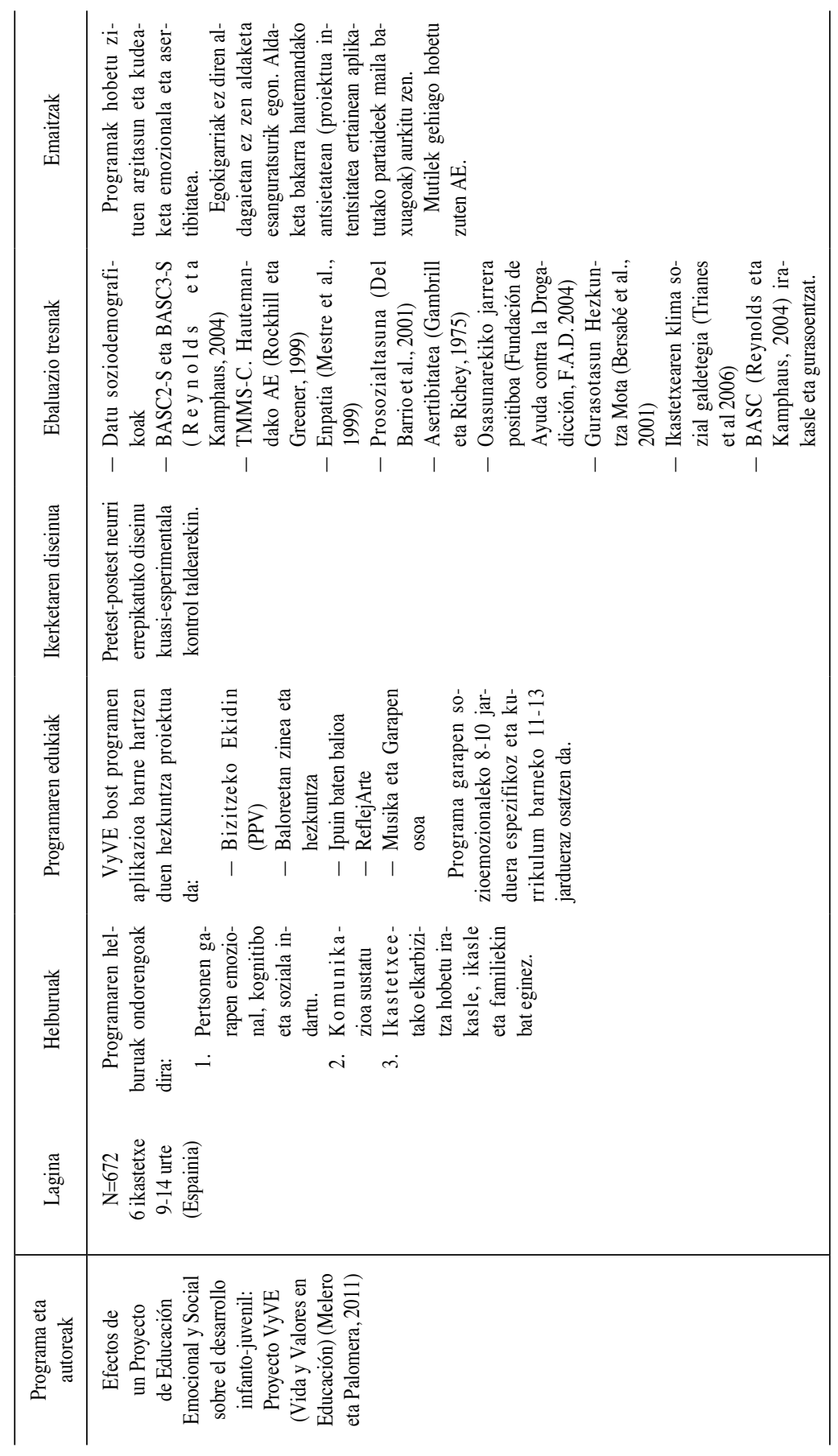

TANTAK, 28 (2), 2016, 111-148 orr. 


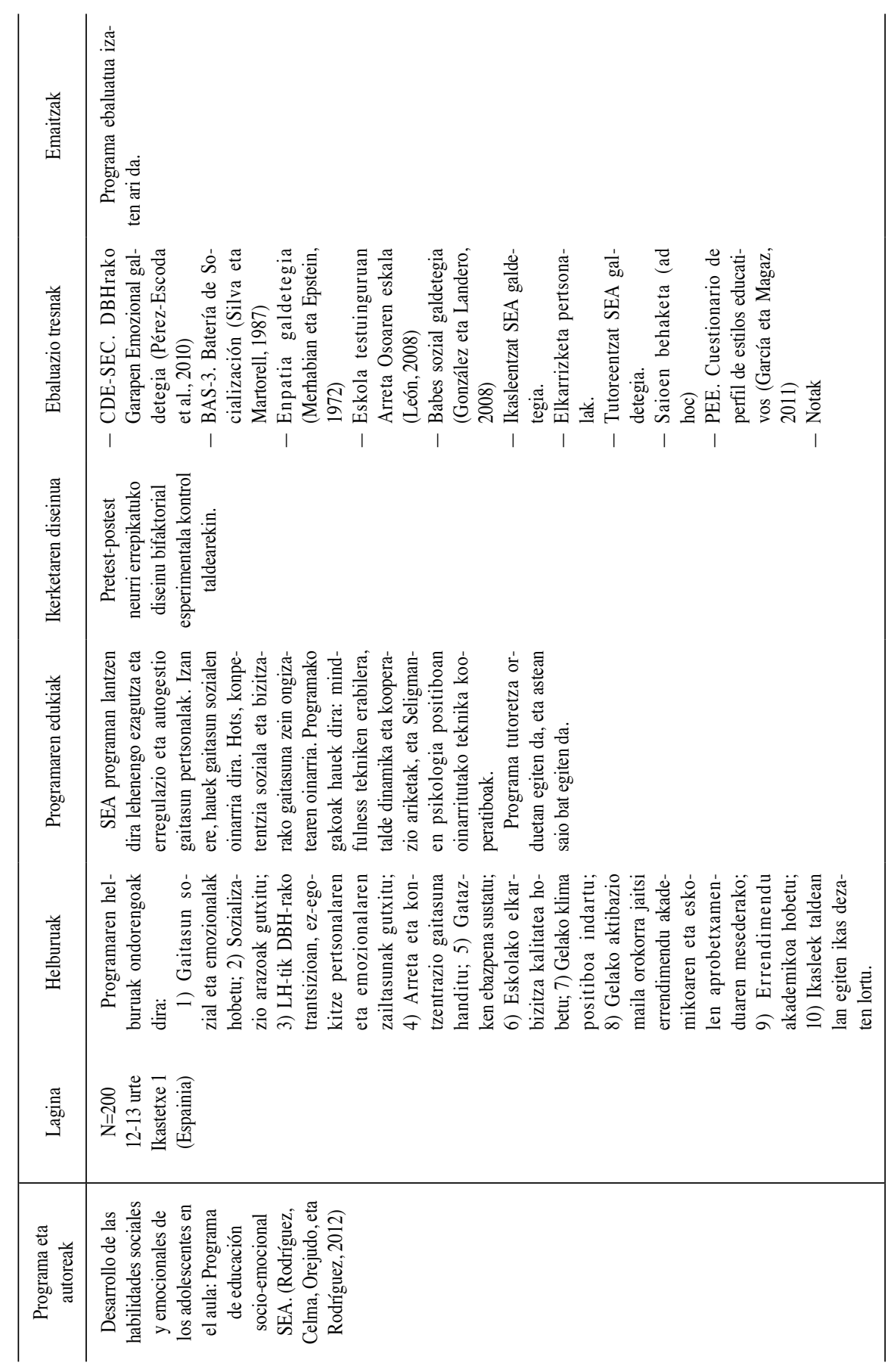




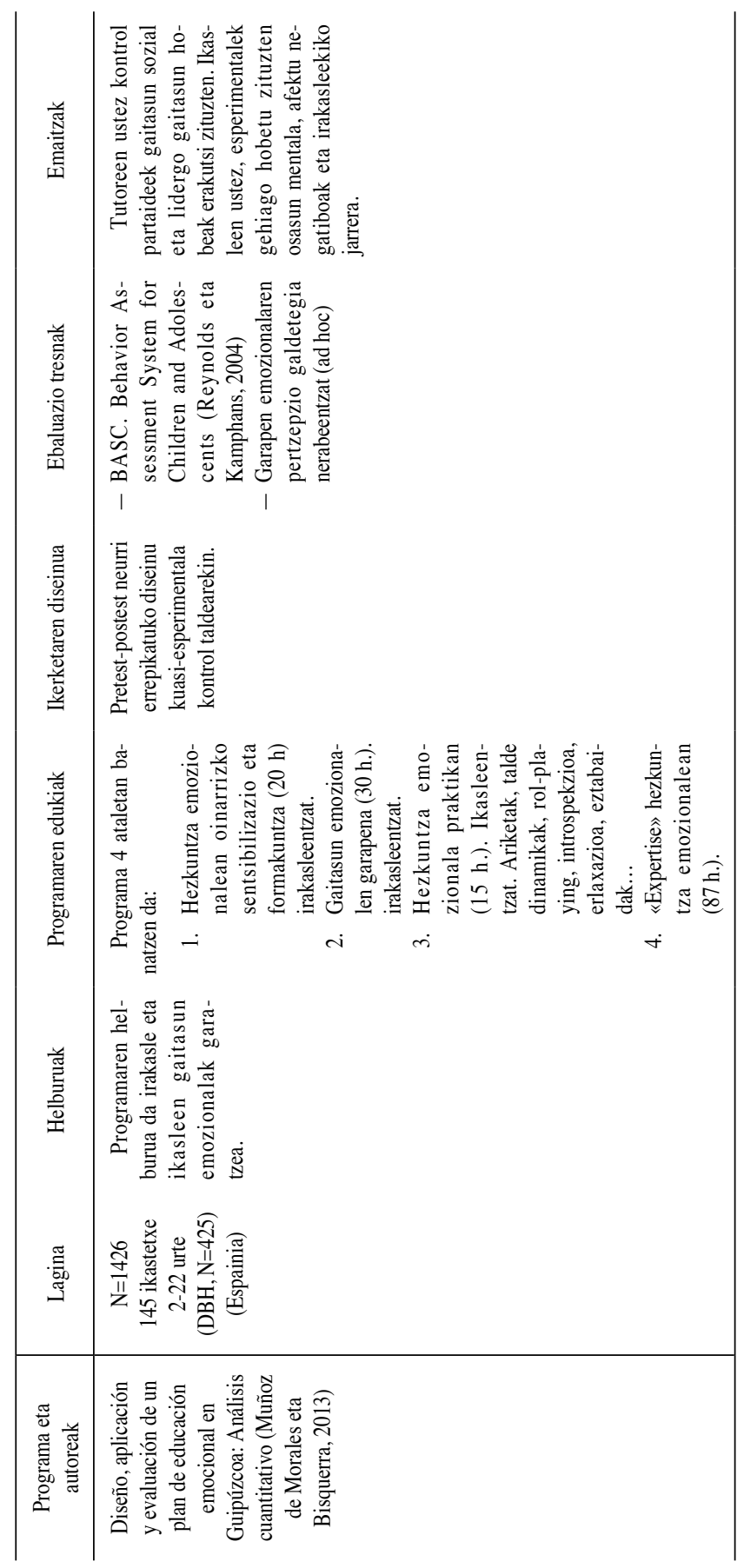

TANTAK, 28 (2), 2016, 111-148 orr. 
Taula horietako emaitzek erakusten dutenez, esku-hartze programek, adimen emozionala hobetzeaz gain, ongizate sozial eta emozionala, hazkuntza morala eta osasun mentala ere hobetzen dituzte, eta baita konpetentzia sozialak, pertsonarteko harremanak, komunikazioa, egokitzapen soziala, kooperazioa, pertsonarteko gaitasun sozialak, onarpen soziala eta helburuak ezartzeko gaitasuna ere. Ikaskuntzarekin loturiko aldagaiak ere hobetzen dituzte; adibidez, errendimendu akademikoa, gelako klima eta eskolarekiko asetasuna, eta enpatia edo bestearen lekuan jartzeko gaitasuna ere. Jokaerari dagokionez, aurkeztutako programek indartzen dituzte jokaeraren autokontrola, diziplina, eta jokaera prosozial eta asertiboak. Era berean, arazoen ebazpena ere sustatzen dute. Gainera, programa horiek gutxitu egiten dituzte delinkuentzia maila, droga kontsumoa, oldarkortasuna, antsietatea, afektu negatiboak, estres soziala, depresioa, somatizazioa, haserrea, etsaitasuna eta larritasuna.

Generoaren aldetik, programa gehienek ez dute aurkitu desberdintasunik AEaren edo gaitasun sozioemozionalaren eta generoaren artean (Choque-Larrauri \& Chirinos-Cáceres, 2009; Eisen et al. 2003; Kimber et al., 2008; Ogunyemi, 2008), baina programa batzuek aurkitu dituzte aldeak neska eta mutilen artean. Halakoetan, mutilek irabazten dute, beren emaitzak esanguratsuki hobetzen baitituzte. Mutilek neskek baino gehiago hobetzen dute beren enpatia (Castillo et al., 2013) eta AE (Melero \& Palomera, 2011). Hala ere, Byrne eta taldekideek (2004) egin zuten ikerketan neskek hobetu zuten gehiago.

Maila sozioekonomikoa kontuan hartu duten bi programek (Flay et al. 2001; Garaigordobil eta Peña, 2014; Garaigordobil eta Peña-Sarrionandia; Sarrionandia eta Garaigordobil, prentsan) ez dute desberdintasunik aurkitu maila desberdineko ikastetxeen artean. Beraz, ondorioztatu daiteke eskuhartze programa horiek modu bertsuan eragiten dutela maila desberdineko partaideengan.

Azkenik, segimendu fasea egin duten ikerketek erakutsi dute, oro har, emaitzak mantendu egiten direla denboran zehar (Eisen et al. 2003; RuizAranda et al. 2012; Garaigordobil eta Peña, 2014; Garaigordobil eta PeñaSarrionandia; Sarrionandia eta Garaigordobil, 2016).

\section{Programa desberdinak}

Gaitasun emozionalak eta sozialak garatzea helburu duten jarduerez osatzen dira arestian aipatutako programa horiek. Hala, jarduera hauek bi multzotan sailka daitezke: batetik, gaitasun emozionalak garatzen dituzten jarduerak daude, eta, bestetik, gaitasun sozialak garatzen dituztenak. Gaitasun emozionalak hobetzen dituzten jarduerak emozioen azterketan oinarritzen dira; hau da, emozioak identifikatu, adierazi, ulertu, erregulatu eta erabiltzeko gaitasuna hobetzea dute helburu. Gaitasun sozialak hobetzea 
helburu duten jardueren helburua, berriz, komunikazio gaitasunak, gatazken ebazpena, pertsonarteko harremanak, etab. hobetzea da.

Programa hauen izaera hobeto erakusteko asmoz, jarraian 3 programa (INTEMO, Skill for adolescence eta Nerabezaroan adimen emozionala hobetzeko programa) azalduko dira. Programa hauek (eta ez beste batzuk) aukeratu izanaren arrazoia izaera desberdinetako programak erakustea izan da. Hau da, mundu mailan ebaluatuak izan diren programa desberdinak ordezkatzen dituzten 3 programa azaltzea. Batetik, «Skills for adolescence» gaitasun sozialak garatzeko programa da. Bestetik, INTEMO eta «Nerabezaroan adimen emozionala hobetzeko programa» gaitasun emozionalak lantzeko programak dira. Hala ere, INTEMO programak gaitasun gisa ulertzen du adimen emozionala (Salovey eta Mayerren ikuspegia oinarritzat hartuz) eta «Nerabezaroan adimen emozionala hobetzeko programa»k ikuspegi mistoa du oinarritzat (Goleman edo Bar-On bezalako ikerlarien teoriak izanik oinarrian). Beraz,ondorengo paragrafoetan ezaugarri eta izaera desberdineko programak ezagutarazten dira.

INTEMO (Castillo, Salguero, Fernández-Berrocal eta Balluerka, 2013) programa AE hobetzen duen programa bat da. Programa hori Salovey eta Mayerren ereduan oinarritzen da, eta hura osatzen duten jardueren helburua da emozioak identifikatu, ulertu, erregulatu eta errazteko gaitasuna garatzea. Programa hau osatzen duten jardueren artean, «Asmatu nor» ariketa dago. «Asmatu nor» jarduera gaitasun emozionalak hobetzeko jarduera bat da, zeinean emozioen pertzepzioa hobetu nahi baita; horretarako, ikasleek taldeka egiten dute lan irudi, bideo, abesti eta bestelakoetan agertzen diren emozioak identifikatuz. Bestalde, emozio horiek adierazten dituzte hainbat bide erabiliz; adibidez, eskulanak sortuz, istorioak asmatuz, marrazkiak eginez... eta, saio amaieran, eztabaidatu egiten da.

Gaitasun sozialei dagokienez, Skills for adolescence (Eisen, Zellman, eta Murray, 2003) programa da gaitasun mota hauek hobetzen dituen programetariko bat. Programa mota hauen helburuak pertsonarteko harremanak, komunikazioa edo asertibitatea bezalako gaitasunak hobetzea da. Skills for adolescence programaren kasu konkretuan, hau osatzen duten jarduerak harremanak hobetzera, estereotipoak guxtitzera... zuzenduta daude. Jarduera adibide gisa «Asmatu nire etiketa» aipa daiteke. Jarduera horren helburua da estereotipoak gutxitzea; horretarako, 6 ikasle gelaren erdian jartzen dira, bakoitzak bekokian etiketa bat duelarik. Etiketa horretan ezaugarri edo jarrera bat azaltzen da («kritika nazazu», «ez egin niri jaramonik», etab.); hala, partaide horien eginbeharra izango da eztabaida bat mantentzea, besteek beren etiketetan jartzen duen bezala tratatzen dutela. Amaieran, denen artean eztabaidatzen da, bakoitzak sentitu duena adierazten du.

AE hobetzen duen beste programa bat da Garaigordobil eta Peña-Sarrionandiarena (Garaigordobil eta Peña, 2014, 2016; Garaigordobil eta Peña-Sarrionandia, 2015; Sarrionandia eta Garaigordobil, 2016). Pro- 
grama horrek bost helburu nagusi ditu: autokontzientzia hobetzea, erregulazio emozionala sustatzea, animo egoera hobetzea, komunikazioa bultzatzea eta enpatia sustatzea. Programak 5 modulutan banatutako 31 jarduera ditu. Lehenengo moduluan, autokontzeientzia garatzen da; horretarako, autokontzientzia emozionala, norbere burua ezagutzea, autokontzeptua, norbere buruarenganako konfiantza izatea eta autoestimua lantzen dira. Bigarren modulua erregulazio emozionalari dagokio; modulu horretan, gaitasun hori hobetzeko, autokontrola, emozio negatiboak gutxitu eta positiboak sustatzeko bideak, garatzen dira emozioak maneiatzeko gaitasuna, bulkaden kontrola eta frustrazioarekiko tolerantzia. Hirugarren moduluak umoreari egiten dio erreferentzia, eta zoriontasuna, baikortasuna eta bizitzarekiko asetasuna lantzen dira modulu horretan. Laugarren modulua komunikazioari dagokio, eta entzuteko eta adierazteko gaitasunak (hitzezkoa zein ez-hitzezkoa) garatzen dira modulu horretan. Azkenik, bosgarren moduluak enpatia lantzea du helburu; beraz, bestearen lekuan jartzeko gaitasuna garatzen da modulu horretan.

Programa horren inplementazioa aurretiko beste programa batzuetan (Garaigordobil, 2008) oinarrituz egin da, eta ondorengo aldagai egonkor hauek ditu kontuan: saioen arteko egonkortasuna (astero 55 minutuko saio bat, 7 hilabetez), espazio-denbora egonkortasuna (asteko egun, ordu eta leku berdinean egiten da beti programa), programa gidatzen duen helduaren egonkortasuna (pertsona berak gidatzen ditu saio guztiak) eta saioen egituraren egonkortasuna (ikasleak zirkuluan elkartu ondoren, helduak azaltzen ditu saioan egingo dena eta garatu nahi diren helburuak. Gero jarduera egiten da, eta, amaieran, zirkuluan jarrita, eztabaidatu egiten da).

Hainbat jarduera eta talde dinamika erabiltzen ditu programak, besteak beste, rol-playingak, ideia-jasak, etab. Behin jarduerak eginda, eztabaida egiten da. Eztabaida horretan, helduak pentsamendu kritikoa eta hausnarketa sustatzen ditu landutako gaien inguruan; horretarako, galderak planteatzen ditu era objektibo batean, iritzirik eman gabe.

Programa horretako jarduera baten adibide dugu «Pertzepzio emozionala». Hala, jarduera horren helburuak dira besteen emozioen identifikazioa eta ulermena, besteen hitzezko eta ez-hitzezko hizkuntzaren pertzepzioa, enpatia eta emozioen analisia hobetzea. Hori lantzeko, ikasleek hainbat bideo (filmak, iragarkiak...) ikusten dituzte, eta talde handian komentatzen dituzte, galdera batzuei jarraituz. Galderak horien adibide dira, besteak beste, «Zer emozio ageri dira bideoan?» eta «Zergatik sentitzen dira horrela?». Azkenik, saioaren amaieran eztabaidatu egiten da: helduak «Zer ikasi duzue gaur?», «Nola identifikatzen dira emozioak?», «Erreza al da bestearen lekuan jartzea?» eta antzeko galdera batzuk planteatzen ditu, saioan zehar landutakoa finkatu eta parteka dezaten ikasleek. 


\section{ONDORIOAK}

Bilaketetan jasotako emaitzek agerian jartzen dute programa psikoedukatiboek, AE eta gaitasun sozioemozionalak hobetzeaz gain, beste alor batzuk (besteak beste, osasuna, ongizatea, pertsonarteko harremanak eta errendimendu akademikoa) ere hobetzen dituztela, zeinek bizitzan berebiziko garrantzia baitute. Beraz, nabarmena da zientifikoki ebaluatutako programak ezartzeak duen garrantzia nerabeen garapen soziala eta afektiboa sustatzeko.

Ikerketa honek hainbat ekarpen egiten dizkio egungo literaturari. Izan ere, lan honek lagundu du AE eta gaitasun sozioemozionalak hobetzeko programen ikerketa eremua argitzen. Hala, ikerlan honek mundu mailan ebaluatu diren programak biltzen, eta programa horiek lortu dituzten emaitzak laburtzen ditu, eta, horri esker, ondorio argiak eskaintzen ditu. Zehazki, berrikusketa honetan jasotako programen emaitzek erakusten dute gaitasun sozialak eta emozionalak hobetzeko esku-hartzeek jokabidezko aldagaiak (droga kontsumoa, indarkeria, etab.) eta psikologikoak (autoestimua, enpatia, etab.) hobetzen dituztela besteak beste. Emaitzek argi uzten dute beraz eskolan gaitasun sozialak eta emozionalak lantzeak osasuna, ongizate psikologikoa eta errendimendu akademikoa bezalako aspektu garrantzitsuak hobetzen dituela. Horrela bada, programa hauek nerabeen garapen integrala sustatzen dute eta horien bizi kalitatea hobetu.

Ekarpenak aipagarriak izan badira ere, ikerlan honek baditu bere mugak, ezaugarri batzuk betetzen zituzten programak baino ez baititu jaso; hau da, nerabezaroan bakarrik oinarritu da berrikusketa. Horrenbestez, eta datuak orokortzeko, interesgarria izango litzateke berrikusketa zabaltzea haur, heldu eta adinekoei zuzenduta dauden programetara. Azkenik, interesgarria izango litzateke bilaketa horiek hizkuntza gehiagotan egitea, programa gehiago aurkitzeko.

Amaitzeko, esan beharra dago lan honek ikerketa lerro berriak zabaltzen dituela. Alde batetik, alderdi teorikoari dagokionez, onuragarria izango litzateke bilaketak zabaltzea parte-hartzaileen adina luzatuz, hizkuntza gehiago erabiliz bilaketak egiteko edo datu base gehiago erabiliz. Beste alde batetik, alde praktikoari dagokionez, mesedegarria izango litzateke inplementatzen diren programa guztien ebaluazio zientifikoak egitea, emaitza fidagarriagoak eta baliogarriagoak edukitzeko; eta mesedegarria izango litzateke, orobat, jarraipenak egitea ere. Azkenik, interesgarria izango litzateke programa horien eragina aztertzea generoaren eta maila sozioekonomikoaren arabera; izan ere, orain arte egindako ikerketak urriak izan dira arlo horretan, eta emaitzak ezin dira orokortu. 
Introduction: since the use of the term emotional intelligence (EI) in 1990, this concept has gained ground by showing to be related to relevant aspects of life such as health, well-being and interpersonal relationships. The interest aroused by this construct has provoked the creation of several programs in order to develop socioemotional abilities. Objectives: the main aim of this study has been to review the EI programs' scientific literature. In particular, the review focuses on evidence-based programs. Method: bibliographic searches of books (ISBN) as well as searches in PsycINFO, ERIC, Scopus and Google Scholar have been conducted. These searches have focused on the material published until 2015 and the terms used have been emotional intelligence, social/emotional skills, program and adolescence. Results: 32 programs have been found. 6 of them develop EI. The other 26 are aimed to promote social and emotional skills. By analysing these programs, the following aspects have been taken into account: programs' denomination, authors, participants, objectives, components, study design, instruments and results. Such results show that the programs that develop EI and/or socioemotional skills, in addition to improving these variables, also promote academic performance, empathy, self-esteem, behaviour self-control, conflict resolution, well-being and mental health; while decreasing delinquency, drug abuse, anxiety, stress and somatization tendency. Discussion: the aforementioned results obtained reveal the importance of implementing evidence-based intervention programs in order to promote the social and emotional development of adolescents.

Keywords: emotional intelligence, programs, adolescence, review.

Introducción: Desde la utilización del término de inteligencia emocional (IE) en 1990, el concepto se ha abierto camino demostrando estar relacionado con factores tan relevantes de la vida como la salud, el bienestar y las relaciones interpersonales. El interés suscitado por dicho constructo ha provocado la creación de numerosos programas para mejorar las competencias socioemocionales. Objetivos: El objetivo de este trabajo ha sido revisar la literatura científica sobre los programas para mejorar la IE. En concreto, la revisión se ha centrado en programas que han sido evaluados. Método: Se han realizado búsquedas bibliográficas de libros (ISBN) así como búsquedas en las bases de datos PsycINFO, ERIC, Scopus y Google Académico. Estas búsquedas se han centrado en el material publicado hasta el 2015 y los términos utilizados en ellas han sido inteligencia emocional, habilidades sociales/emocionales, programa 
y adolescencia. Resultados: Se han encontrado 32 programas. 6 de estos programas desarrollan la IE. Otros 26 tienen como finalidad el desarrollo socioemocional. A la hora de analizar estos programas se han tenido en cuenta la denominación de los programas, sus autores, la muestra, los objetivos y componentes del programa, el diseño de investigación, los instrumentos y los resultados. Los resultados evidencian que los programas que desarrollan la IE y/o las competencias socioemocionales, además de mejorar estas variables también mejoran el rendimiento académico, la empatía, la autoestima, el autocontrol de las conductas, la resolución de conflictos, el bienestar y la salud mental, al mismo tiempo que disminuyen la delincuencia, el consumo de drogas, la ansiedad, el estrés y la tendencia a la somatización. Discusión: Los resultados obtenidos ponen de manifiesto la importancia de implementar programas de intervención basados en la evidencia para fomentar el desarrollo social y emocional de los adolescentes.

Palabras clave: inteligencia emocional, programas, adolescencia, revisión.

Introduction: depuis l'utilisation du terme intelligence émotionnelle (IE) en 1990, le concept a fait son chemin et a montré être lié à des facteurs aussi pertinents que la santé, le bien-être et les relations interpersonnelles. L'intérêt suscité par cette variable a provoqué la création de nombreux programmes pour améliorer des compétences socio-émotionnelles. Objectifs: l'objectif de ce projet a été revoir la littérature scientifique des programmes pour développer les programmes d'IE. En particulier, la révision a porté sur les programmes qui l'ont fait évaluer. Méthode: des recherches bibliographiques (ISBN) ainsi que des recherches sur PsycINFO, ERIC, Scopus et Google Académico ont été réalisées. Ces recherches ont porté sur des documents publiés jusqu'en 2015 et les mots utilisés ont été l'intelligence émotionnelle, compétences sociales/émotionnelles, programme et adolescence. Résultats: 32 programmes ont été trouvés. 6 de ces programmes développent l'intelligence émotionnelle. Les autres 26 programmes ont pour finalité le développement de compétences émotionnelles. En analysant ces programmes, la dénomination du programme, les auteurs, les participants, les objectifs et les components du programme, la conception de recherche, les instruments et les résultats ont été pris en compte. Les résultats mettent en évidence que les programmes pour améliorer l'IE et les compétences socio émotionnelles, ainsi que leurs variables, améliorent aussi les résultats scolaires, l'empathie, l'estime de soi, l'autocontrôle de la conduite, la résolution des problèmes, le bien-être et la santé mentale; en même temps qu'ils diminuent la délinquance, la consommation de drogues, l'anxiété, le stress et la tendance pour la somatisation. Discussion: les résultats obtenus mettent en évidence l'importance d'implémenter des programmes d'interven- 
tion évalués pour promouvoir le développement social et émotionnel des adolescents.

Mots-clé: l'intelligence émotionnelle, programmes, adolescence, révision

\section{ERREFERENTZIAK}

Aciego de Mendoza, R., Domínguez, R., eta Hernández, P. (2003). Evaluación de la mejora en valores de realización personal y social en adolescentes que han participado en un programa de intervención. Psicothema, 15(4), 589-594.

Alonso-Gancedo, N., eta Iriarte, C. (2006). Relaciones entre el desarrollo emocional y moral a tener en cuenta en el ámbito educativo: propuesta de un programa de intervención. Revista Electrónica de Investigación Psicoeducativa, $8(4), 177-212$.

Bloom, D.E., Cafiero, E.T., Jané-Llopis, E., Abrahams-Gessel, S., Bloom, L.R., Fathima, S. eta Weinstein, C. (2011). The global economic burden of noncommunicable diseases. Geneva: World Economic Forum.

Brackett, M., Rivers, S., Reyes, M., eta Salovey, P. (2010). Enhancing academic performance and social and emotional competence with the RULER feeling words curriculum. Learning and Individual Differences, 22(2), 218-224. doi:10.1016/j.lindif.2010.10.002

Byrne, M., Barry, M., eta Sheridan, A. (2004). The development and evaluation of a mental health promotion programme for post-primary schools in Ireland. (WFMH/WHO Publication). http://www.nuigalway.ie/health-promotion/ documents/M_Barry/2004_bc_mindout_country_case_studies.pdf webgunetik berreskuratua.

Castillo, R., Salguero, J. M., Fernández-Berrocal, P., eta Balluerka, N. (2013). Effects of an emotional intelligence intervention on aggression and empathy among adolescents. Journal of Adolescence, 36, 883-892. doi:10.1016/j.adolescence.2013.07.001

Castillo, R., Salguero, J. M., Fernández-Berrocal, P., eta Balluerka, N. (2013). Effects of an emotional intelligence intervention on aggression and empathy among adolescents. Journal of Adolescence, 36, 883-892. doi:10.1016/j. adolescence.2013.07.001

Choque-Larrauri, R., eta Chirinos-Cáceres, J. L. (2009). Eficacia del Programa de Habilidades para la Vida en Adolescentes Escolares de Huancavelica, Perú. Revista Española de salud pública, 11(2), 169-181. doi:10.1590/S012400642009000200002

Carpintero, E., López, F., Del Campo, A., Soriano, S., eta Lázaro, S. (2007). El bienestar personal y social de los adolescentes y la prevención del malestar y la violencia: Presentación y validación de un programa educativo. Revista de Investigación en Psicología, 10(2), 29-41. 
Castro, S. (2006). The effects of a culturally-adapted social-emotional learning curriculum on social-emotional and academic outcomes of Latino immigrant high school students. (Argitaratu gabeko tesia). University of Oregon, Eugene.

Cook, T., Murphy, R., eta Hunt, D. (2000). Comer's School Development Program in Chicago. A Theory-Based Evaluation. American Educational Research Journal, 37(2), 535-597. doi:10.3102/00028312037002535

Di Fabio, A., eta Kenny, M. (2011). Promoting emotional intelligence and career decision making among Italian high school students. Journal of Career Assessment, 19(1), 21-34. doi:10.1177/1069072710382530

Durlak, J. A., Weissberg, R. P., Dymnicki, A. B., Taylor, R. D., eta Schellinger, K. B. (2011). The impact of enhancing students' social and emotional learning: A meta-analysis of school based universal interventions. Child Development, 82(1), 405-432. doi:10.1111/j.1467- 8624.2010.01564.x

Eisen, M., Zellmanb, G., eta Murray, D. (2003). Evaluating the Lions-Quest «Skills for Adolescence» drug education program. Second-year behavior outcomes. Addictive Behaviors, 28, 883-897. doi:10.1016/S03064603(01)00292-1

Eisen, M., Zellmanb, G., eta Murray, D. (2003). Evaluating the Lions-Quest «Skills for Adolescence» drug education program. Second-year behavior outcomes. Addictive Behaviors, 28, 883-897. doi:10.1016/S03064603(01)00292-1

Flay, B., Allred, C., eta Ordway, N. (2001). Effects of the Positive Action Program on Achievement and Discipline: Two Matched-Control Comparisons. Prevention Science, 2(2), 71-89.

Freedman, J. (2003). Key lessons from 35 years of social-emotional education: how self-science builds self-awareness, positive relationships, and healthy decision-making. Perspectives in Education, 21(4), 69-80.

Garaigordobil, M. (1999). Diseño y evaluación de un programa de intervención psicoeducativa para la educación en derechos humanos durante la adolescencia. En Premios Nacionales de Investigación Educativa 1998 (pp. 117-150). Madril: Ministerio de Educación y Cultura. CIDE. Colección Investigación n. ${ }^{\circ} 142$.

Garaigordobil, M. (2001). Intervención con adolescentes: Impacto de una experiencia en la asertividad y en las estrategias cognitivas de afrontamiento de situaciones sociales. Psicología Conductual, 9 (2), 221-246.

Garaigordobil, M. (2002a). Assessment of an intervention on social behavior, intragroup relations, self-concept and prejudiced cognitions during adolescence. International Journal of Psychology and Psychological Therapy, 2(1), 1-22.

Garaigordobil, M. (2002b). Esku-Hartze psikologikoa nerabeengan. Nortasunaren garapenerako eta giza eskubideen arloko hezkuntzarako programa. Bilbao: Euskal Herriko Unibertsitateko Argitalpen Zerbitzua.

Garaigordobil, M. (2004). Effects of a psychological intervention on factors of emotional development during adolescence. European Journal of Psychological Assessment, 20(1), 66-80. doi:10.1027/1015-5759.20.1.66

Garaigordobil, M. (2008). Intervención psicológica con adolescentes. Un programa para el desarrollo de la personalidad y la educación en derechos humanos. (2. edizioa) Madril: Pirámide. (Jatorrizko lana 2000.urtean argitaratua).

Garaigordobil, M. (2013). Cyberbullying. Screening de acoso entre iguales. Madril: TEA. 
Garaigordobil, M., eta Peña, A. (2014). Intervención en las habilidades sociales: efectos en la inteligencia emocional y la conducta social. Behavioral Psychology/Psicología Conductual, 22, 551-567.

Garaigordobil, M., eta Peña, A. (2016). Emotional intelligence in adolescents from 13 to 16 years: Explanatory variables. In R. Bowers (Zuz.), Psychological Well-Being: Cultural Influences, Measurement Strategies and Health Implications (101-128 orr.). New York: Nova Science Publishers.

Garaigordobil, M., eta Peña-Sarrionandia, A. (2015). Effects of an emotional intelligence program in variables related to the prevention of violence. Frontiers in Psychology, 6, 743. doi:10.3389/fpsyg.2015.00743

Goleman, D. (1995). Emotional intelligence. New York: Bantam Books.

Gore, S. W. (2000). Enhancing students emotional intelligence and social adeptness. (Argitaratu gabeko tesia). St. Xavier University, Chicago.

Humphrey, N. Lendrum, A., eta Wigelsworth, M. (2010). Social and emotional aspects of learning (SEAL) programme in secondary schools: national evaluation. London: Department of Education. eScholarID:93729.

Kotsou, I., Grégoire, J., Nelis, D., eta Mikolajczak, M. (2011). Emotional plasticity: conditions and effects of improving emotional competence in adulthood. Journal of Applied Psychology, 96, 827-839.

Kiger, D. (2000).The Tribes Process: Phase III Evaluation Executive Summary. School District of Beloit.

Kimber, B., Sandell, R., eta Bremberg, S. (2008). Social and emotional training in Swedish schools for the promotion of mental health: an effectiveness study of 5 years of intervention. Health Education Research, 23(6), 931-940. doi:10.1093/her/cyn040

LeCroy, C. W., eta Rose, S. D. (1986). Evaluation of preventive interventions for enhancing social competence in adolescents. Social Work Research and Abstracts, 22, 8-17. doi:10.1093/swra/22.2.8

Mayer, J., Salovey, P., eta Caruso, D. (2004). Emotional intelligence: Theory, findings, and implications. Psychological Inquiry, 15, 197-215. doi:10.1207/ s15327965pli1503_02

Mikolajczak, M., Roy, E., Luminet, O., Fillée, C., eta de Timary, P. (2007). The moderating impact of emotional intelligence on the free cortisol responses to stress. Psychoneuroendocrinology, 32, 1000-1012.

Mikolajczak, M., Avalosse, H., Vancorenland, S., Verniest, R. Callens, M. van Broeck, N. Fantini-Hauwel, C., eta Mierop, A. (2015). A Nationally Representative Study of Emotional Competence and Health. Emotion, 15(5), 653667. doi:10.1037/emo0000034

Mestre, M. V., eta Frías, M. D. (1996). La mejora de la autoestima en el aula. Aplicación de un programa para niños en edad escolar (11-14 años). Revista de Psicología General y Aplicada, 49, 279-290.

Melero, M. A., eta Palomera, R. (2011). Efectos de un Proyecto de Educación Emocional y Social sobre el desarrollo infanto-juvenil. www.fundacionbotin. org webgunetik berreskuratua.

Muñoz de Morales, M., eta Bisquerra, R. (2013). Diseño, aplicación y evaluación de un plan de educación emocional en Guipúzcoa: Análisis cuantitativo. eduPsykhé, 12(1), 3-21. 
Monjas, M. I. (1997). Programa de enseñanza de habilidades de interacción social. Madril: CEPE.

O’Boyle, E.H., Humphrey, R.H., Pollack, J.M., Hawver, T.H., eta Story, P.A. (2011). The relation between emotional intelligence and job performance: a meta-analysis. Journal of Organizational Behavior Management, 32, 788818. doi:10.1002/job.714

O’Hearn, T., eta Gatz, M. (1999). Evaluating a psychosocial competence program for urban adolescents. The Journal of Primary Prevention, 20(2), 119-124.

Obiols, M. (2005). Diseño, desarrollo y evaluación de un programa de educación emocional en un centro educativo. Revista Interuniversitaria de Formación del Profesorado, 19(3), 137-152.

Ogunyemi, A. (2008). Efectos medidos de técnicas de provocación y de dominio emocional en el fomento de la inteligencia emocional con adolescentes nigerianos. Electronic Journal of Research in Educational Psychology, 6(15), 281296.

OME (2014). Preventing suicide: a global imperative. http://www.who.int/mental_ health/suicide-prevention/world_report_2014/en/webgunetik berreskuratua

Pérez-González, J. C., Cejudo, J., eta Benito-Moreno, S. (2014). Teoría y práctica de la educación emocional. Madril: McGraw-Hill.

Petrides, K.V., eta Furnham, A. (2001). Trait emotional intelligence: Psychometric investigation with reference to established trait taxonomies. European Journal of Personality, 15, 425-448. doi:10.1002/per.416

Qualter, P., Whiteley, H.E., Hutchinson, J.M., eta Pope, D.J. (2007). Supporting the development of emotional intelligence competencies to ease the transition from primary to high school. Educational Psychology in Practice, 23(1), 7995. doi: $10.1080 / 02667360601154584$

Rodríguez-Ledo, C., Celma, L., Orejudo, S., eta Rodríguez-Barreiro, L. (2012). Programa de educación socio-emocional SEA: desarrollo de las habilidades sociales y emocionales para jóvenes con técnicas de atención plena. ISEP Science, 3, 29-40.

Ruiz-Aranda, D., Extremera, N., eta Pineda-Galán, C. (2014). Emotional Intelligence, life satisfaction and subjective happiness in female student health professionals: The mediating effects of perceived stress. Journal of Psychiatric and Mental Health Nursing, 21, 106-113. doi:10.1111/jpm.12052

Ruiz-Aranda, D., Castillo, R., Salguero, J.M., Cabello, R., Fernández-Berrocal, P., eta Balluerka, N. (2012). Short and midterm effects of emotional intelligence training on adolescent mental health. Journal of Adolescent Health, 51, 462467. doi:10.1016/j.jadohealth.2012.02.003

Salazar, R. (2012). Lehen Hezkuntzako azken zikloan gaitasun emozionalak eta eskola elkarbizitza positiboa bultzatzeko esku-hartzea. Tantak, 24(2), 7-25.

Sanz de Acedo, M.L., Ugarte, M.D., Cardelle-Elawar, M., Iriarte, M.D., eta Sanz de Acedo, M.T. (2003). Enhancement of self-regulation, assertiveness, and empathy. Learning and Instruction, 13, 423-439. doi:10.1016/S09594752(02)00026-9

Sánchez, A.M., Rivas, M.T., eta Trianes, M.V. (2006). Effectiveness of an intervention program for improving school atmosphere: some results. Electronic Journal of Research in Educational Psychology, 9, 4(2), 353-370. 
Sarrionandia, A., eta Garaigordobil, M. (2016). Efectos de un programa de Inteligencia Emocional en factores socio-emocionales y síntomas psicosomáticos. Revista Latinoamericana de Psicología. doi: 10.1016/j.rlp.2015.12.001

Weissberg, R. P., Barton, H. A., eta Shriver, T. P. (1997). The social competence promotion program for young adolescents. In G. W. Albee, \& T. P. Gullotta (Zuz.), Primary prevention works, (pp. 268-290). Thousand Oaks, CA: Sage Publications. 